IJHER International Journal of Humanities and Educational Research ISSN: 2757-5403

Volume 4, Issue 1, February 2022

Received: $25 / 12 / 2021$

Accepted: 09/01/2022

Published: 01/02/2022

\title{
THE PANORAMIC SOCIAL NOVEL IN MODERN HEBREW LITERATURE READING IN SAMI MICHAEL'S FICTION
}

\author{
Baydaa Abbas ALI ${ }^{1}$
}

Dr, University of Baghdad, collage of languages, Iraq

\begin{abstract}
Sami Mikhail's novel productions have recently received considerable attention from critics, scholars and researchers around the world. Perhaps this is due to the fact that his literary products serve as an artistic tool for awareness of the fate of the Jewish immigrant or citizen and his psychology and behaviors, and the daily reality lived and lived by the Iraqi or Israeli society, and the issues and transformations that occur in the life of the Israeli, as well as thanks to its artistic formulation and its substantive objectives. Many analysts saw Sami Michael's novels as a reflection of society and its current reality. Sami Michael was distinguished by his choice of the panoramic novel model because it is a mirror of the Israeli society with all its satisfactory and illuminated details, which may be difficult to engage in other literary genres, especially in monitoring social transformations, cultural changes, environmental and living developments and their repercussions in the lives of Israeli immigrants in the past century and the present century. Thinking and behaviors in society, as well as a clear expression of the traditions and values of Israeli society, addressing issues of concern to man, and the accounts of Sami Michael the Israeli-Jewish-Iraqi individual, And his concerns and issues and conflicts intellectual, psychological, cultural and emotional, and presented many solutions to the problems related to his existence and psychological and social conflicts, according to the vision of the author.
\end{abstract}

Key words: Sami Michael, Panoramic Social Novel, Israeli Literature.

http://dx.doi.org/10.47832/2757-5403.12.17

1 (D) bbaydaaabbas@ colang.uobaghdad.edu.iq, https://orcid.org/0000-0002-4266-883X 


\title{
رواية الاجتماعية البانورامية في الأدب العبري العديث قراءة في الأدب الروائي لسامي ميخائيل
}

\author{
بيداء عباس علي

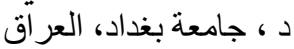

الماخص

حظيت نتاجات سامي ميخائيل الرو ائية في الآونة الأخيرة باهتمام كبير من النقاد و الدارسين و الباحثين في كافة أنحاء العالم.

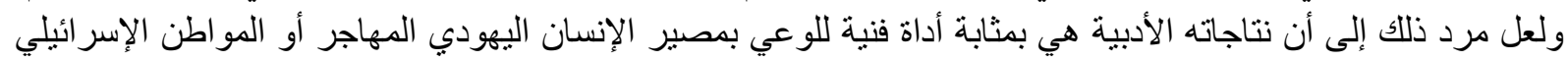

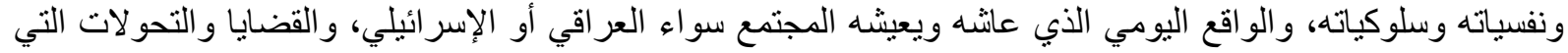

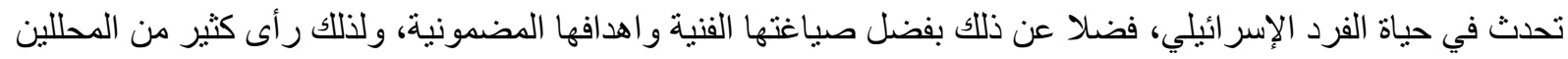

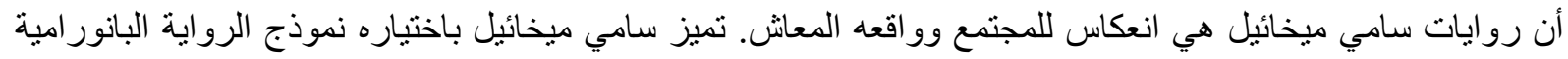

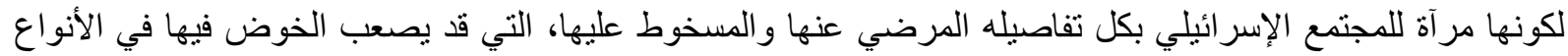

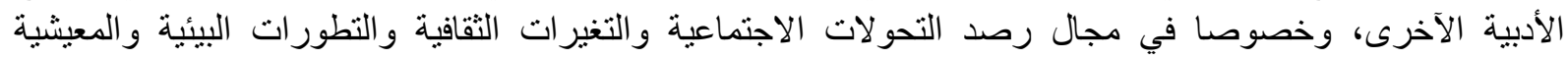

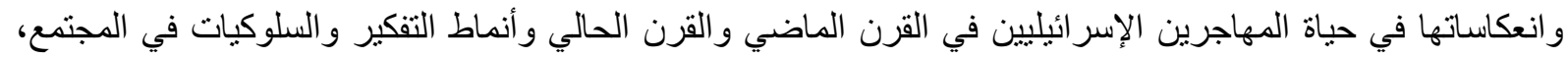

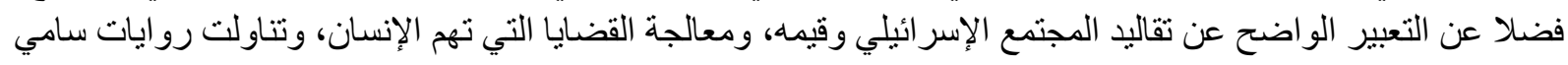

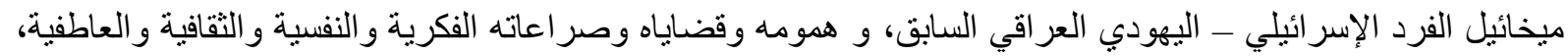

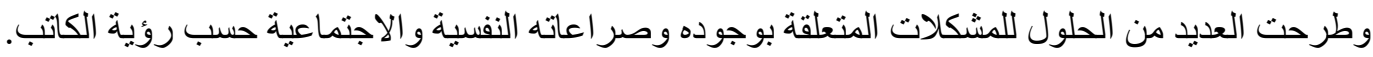

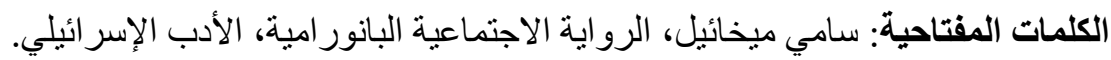

المقدمة:

يطر ح الدارسون سؤ الا معقدا يقول:هل تعد الكتابة الوجه الآخر و البديل للو اقع المعيش بما يطرحه النص على لقد لسان

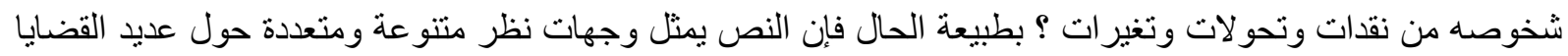

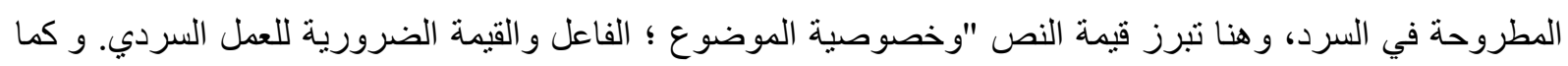

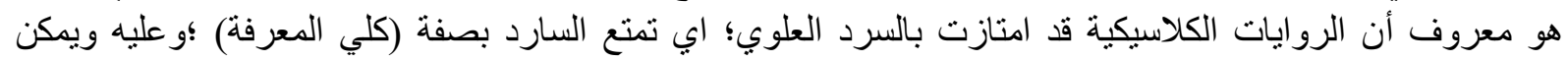

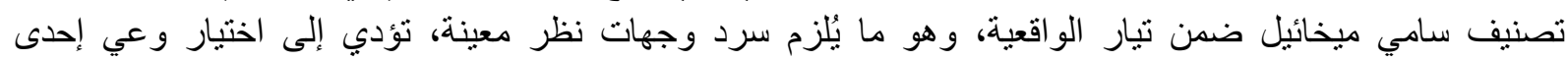

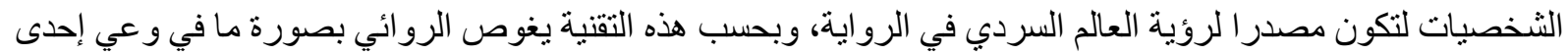

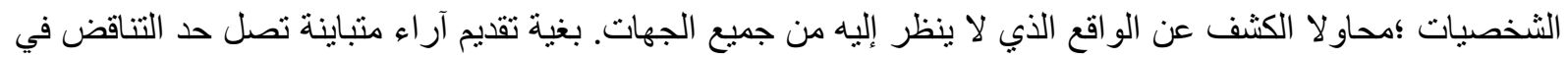
بعض الأحيان.

سؤال البحث

إن الغياب الو اضح للروايات الاجتماعية البانور امية في تاريخ الأدب العبري الجديد يستدعي، في سياق مناقتشتا،

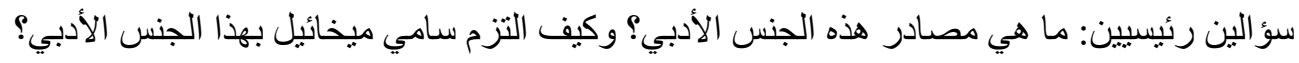

اسباب اختيار البحث

واحدة من الحقائق الأكثر وضوحا في دراسة الرواية العبرية هو عدم وجود أي دراسة حقيقية للرواية البانور امية.

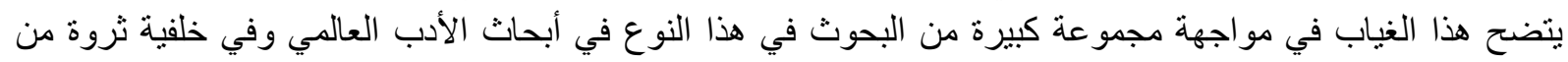

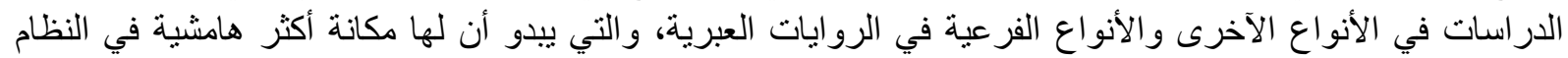

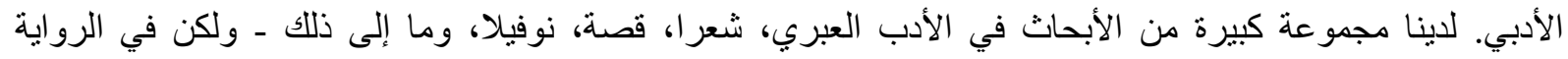

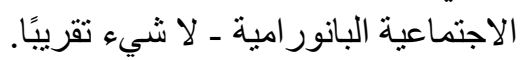


يتفق النقاد على وجود أنواع رئيسية للرواية، وهي: الرواية الاجتماعية والتاريخية والبوليسية والسيكولوجية

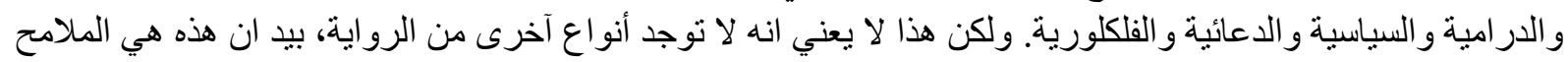
الرئيسية للفن الروائي ( راغب، 1987 )

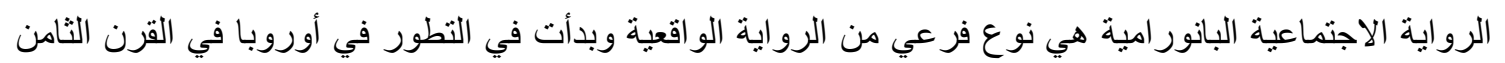

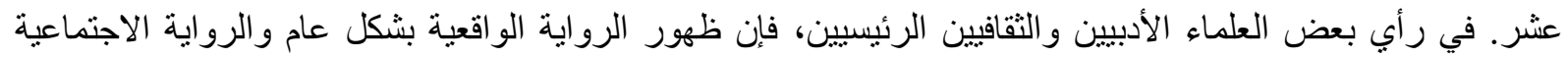

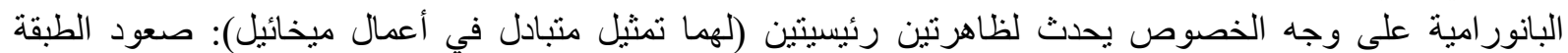

الوسطى و الطبقة المتوسطة التافهة في أوروبا،وظهور مفهوم الأمة و القومية في سياقها الحديث. (Armstrong, 1987) وتدرس الرواية الاجتماعية اثر الوضع الاقتصادي والاجتماعي في فترة ومكان معينين على السلوك الانسي الانساني.

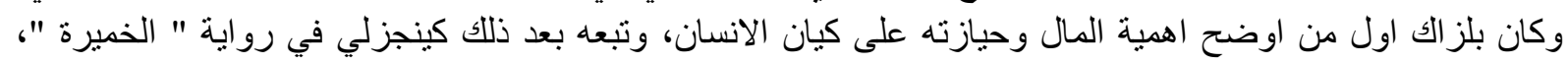

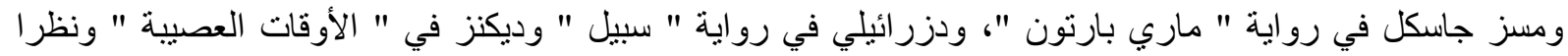

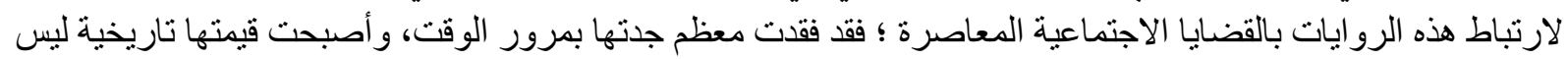

إلا (Burgess, 1967).

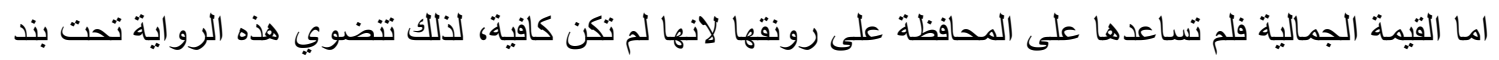

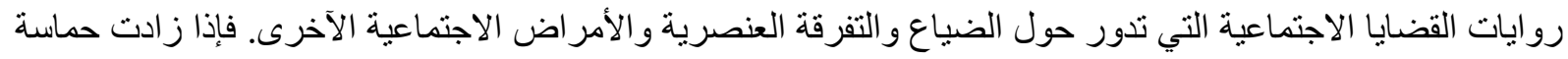

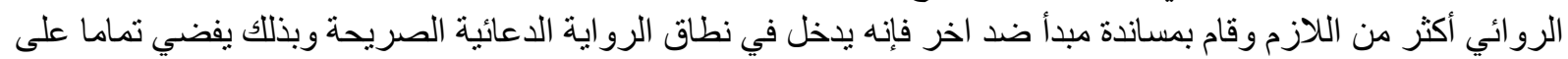
القيمة الفنية للرواية (راغب، ألرمن 1987 )

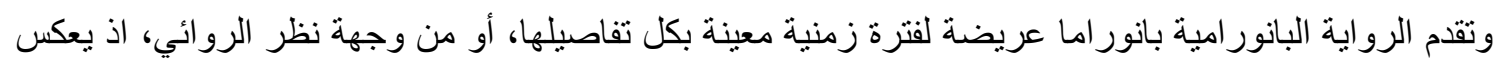

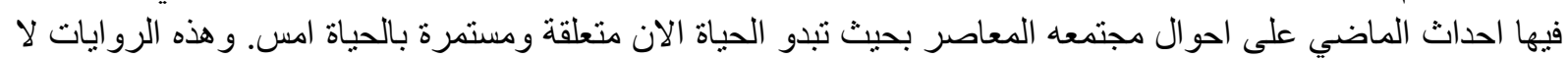

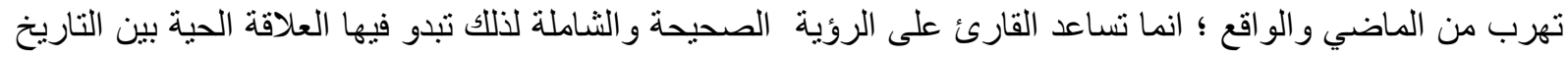

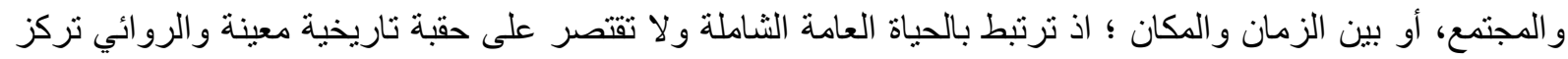

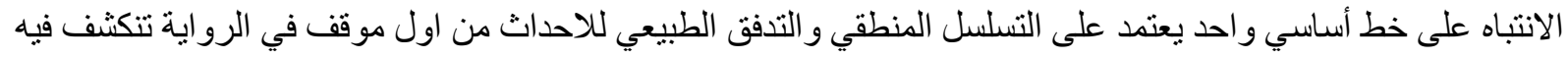

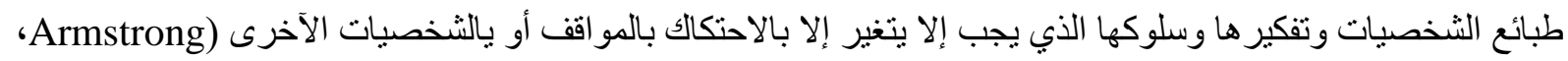
.(1987

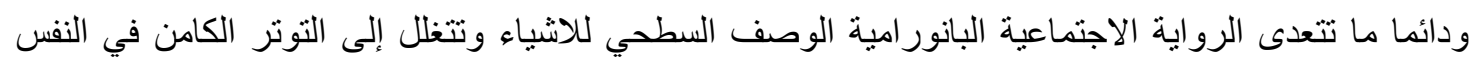
البشرية، الذي عليه يقوم الصراع في اية رواية، و هنا يكون الروائي ملزما إلى التئية التركيز و التكثيف وليس إلى التئ التوضيح و التحليل(Doody, 1996)

أما بخصوص بناء الرواية؛ وتتميز الرواية البانور امية بأنها فضفاضة العقدة، و أنها لا نركز على قضية أو مسألة

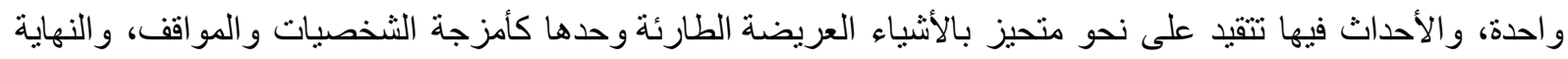

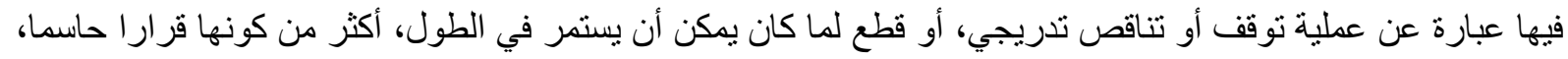

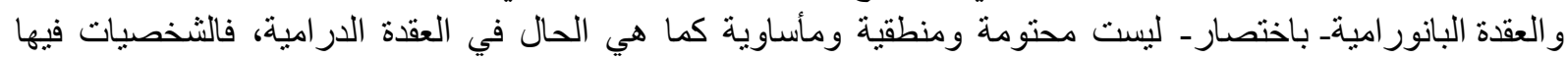
عديدة ونمطية أكثر من كونها فردية، فيما عدا شخصية واحدة كثثبر ا ما تحتكر الانتباه (McKeon, 1987)

\section{الرواية الاجتماعية البانورامية في الأدب العبري الحديث}

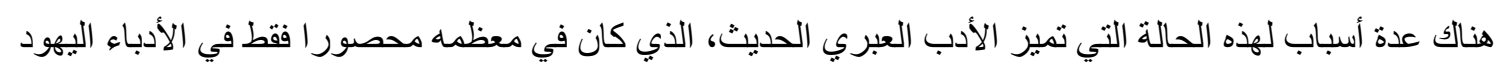

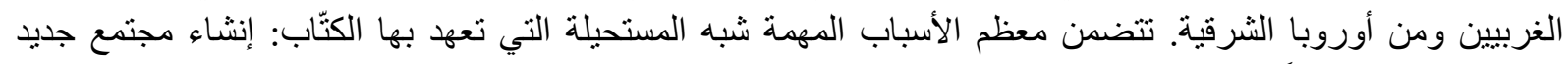

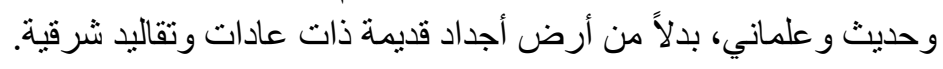

فضلا على هذا، ان مقدرة الأدباء العبريين من كتابة روايات اجتماعية بانور امية كانت محدودة لسببين هما:

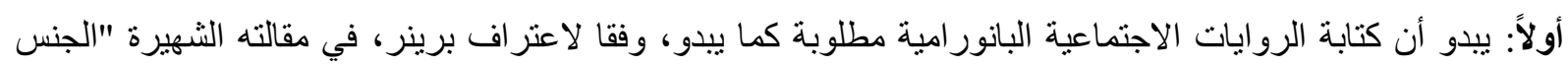

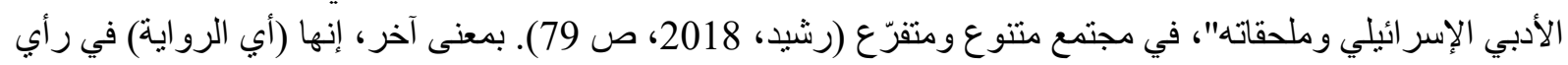


الجميع، كان لها تأثير كبير على تاريخ كتابة النثر العبري في إسرائيل، وربط برينر بين كتابة الرواية البانورامية

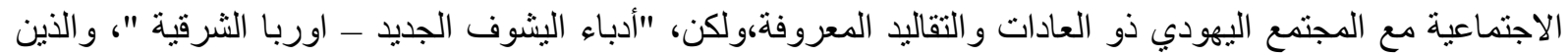

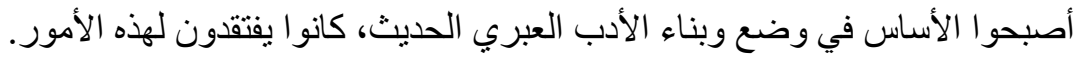

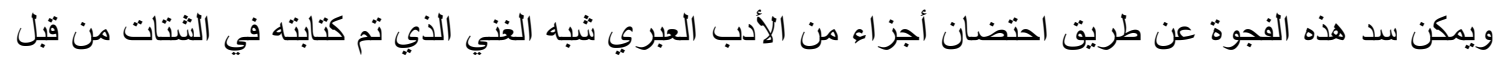

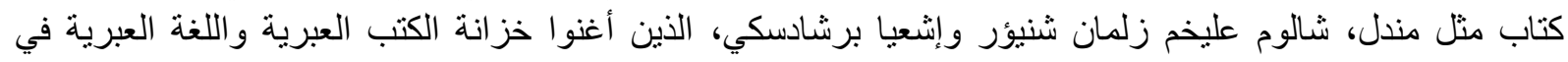

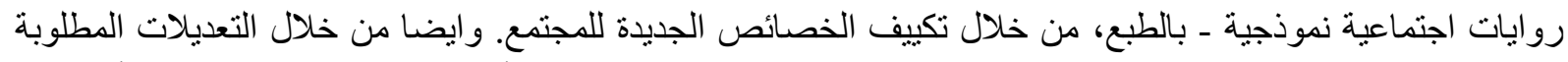

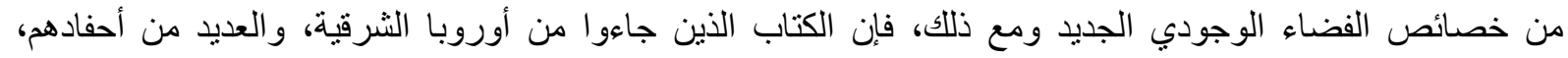

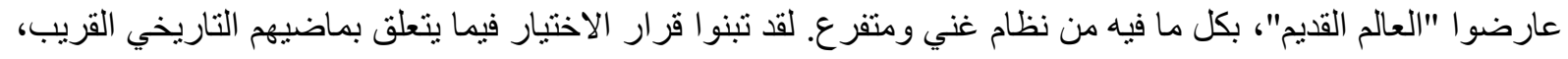

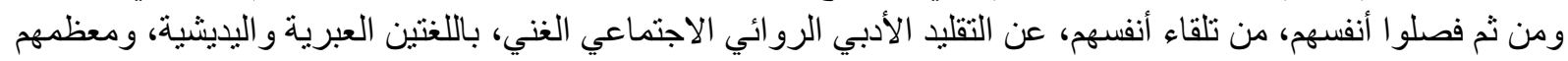
لم يجدو بديلاً له (Hoffman, 2004).

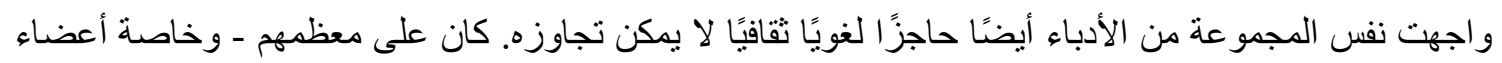

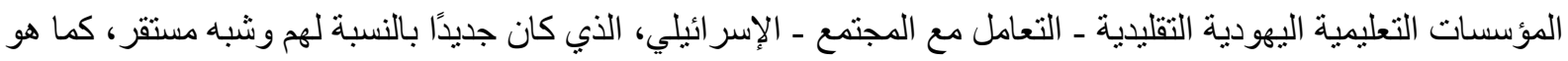

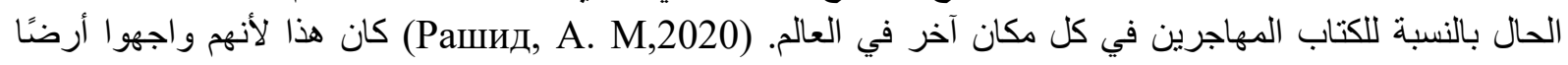

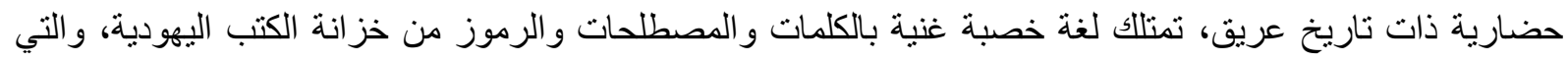

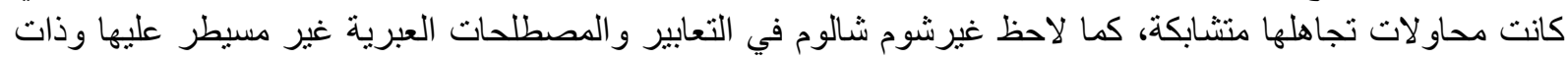

نبرة دينية متفجرة.) (Kuzar, 2001)

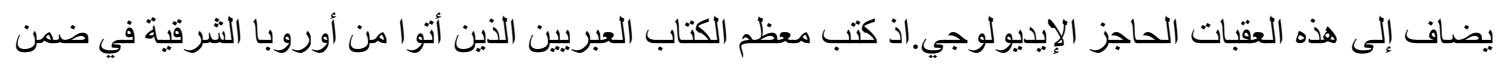

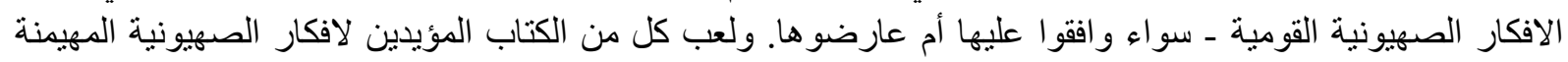

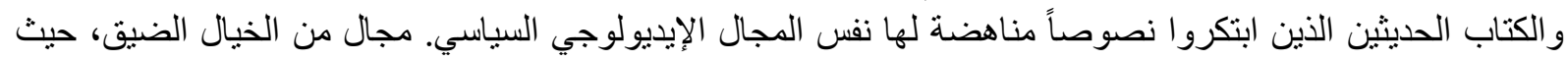

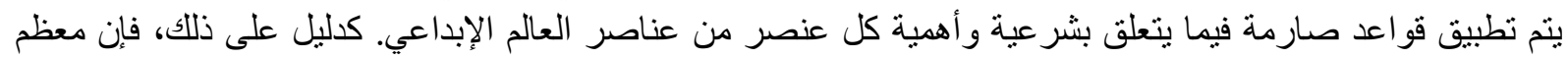

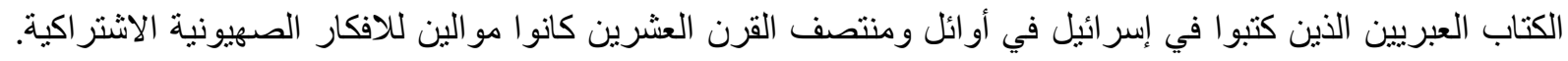

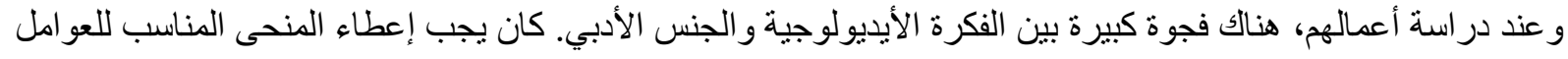

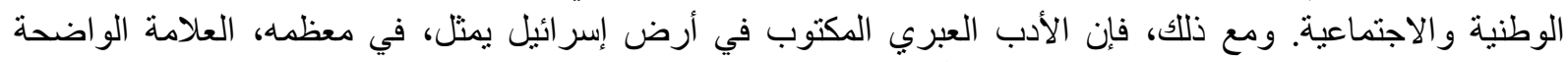

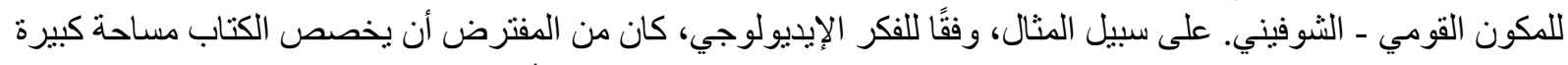

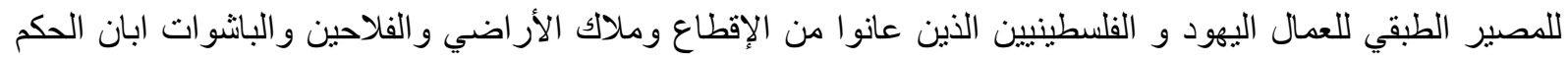

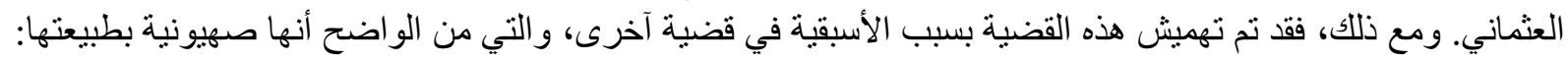

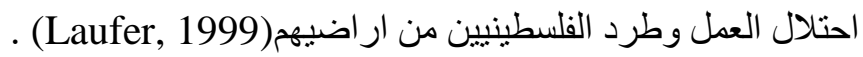

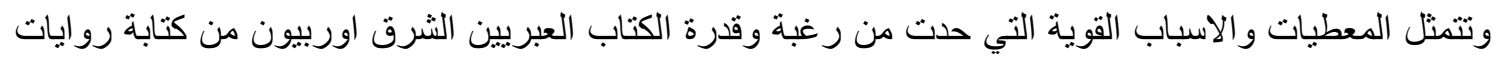

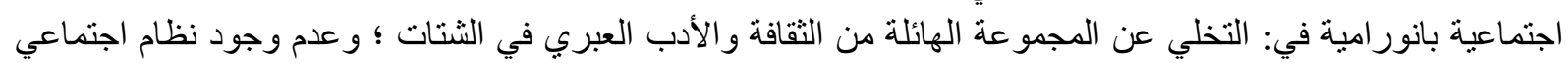

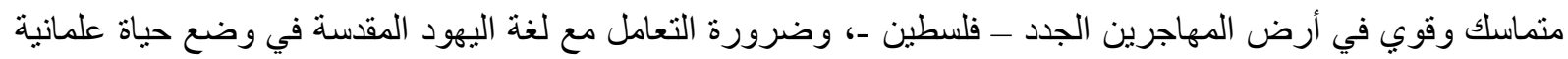

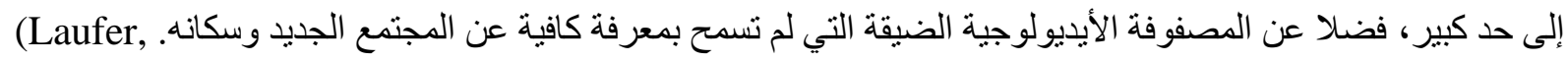




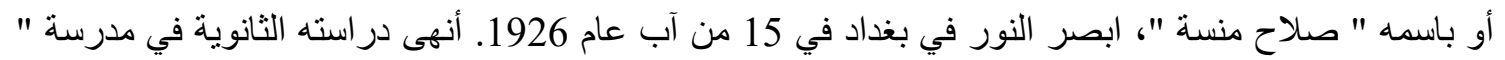

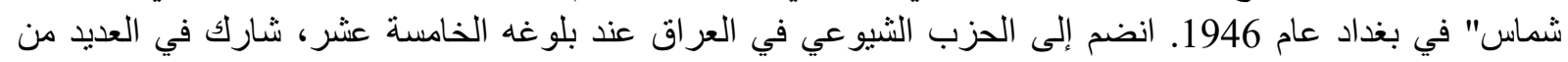

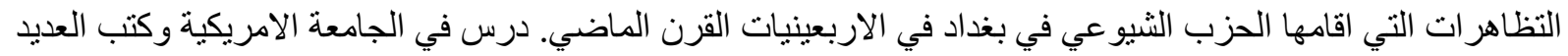

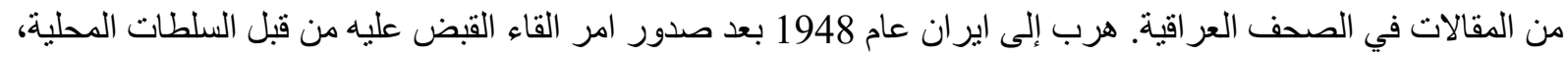

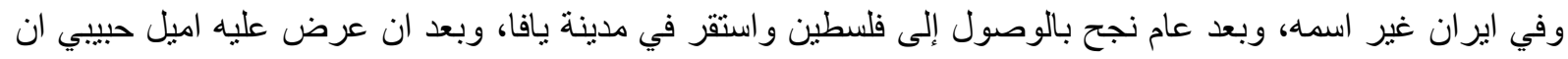

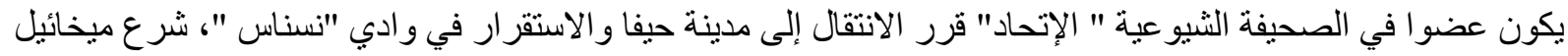

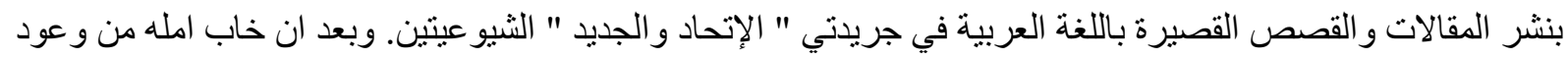

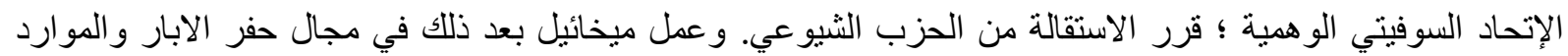

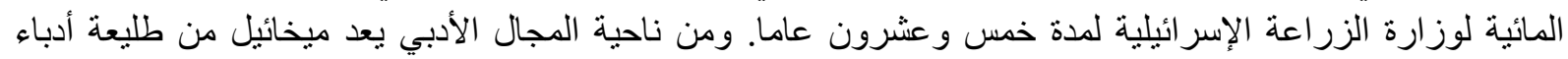

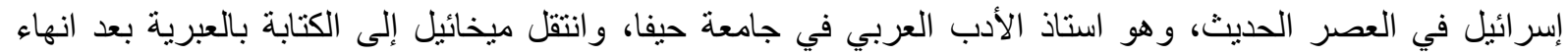

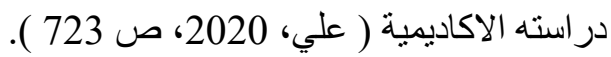

نتاجاته

تمتاز نتاجات ميخائيل الأدبية بتتوعها وجماليتها. حيث شرع بالكتابة في إسرائيل بنشر مقالات وقصص فئ إنساء

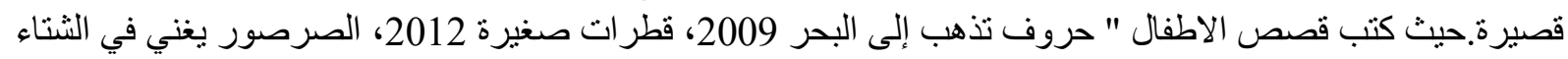

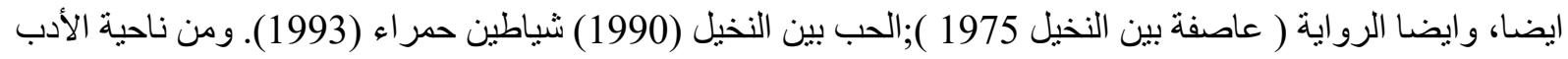

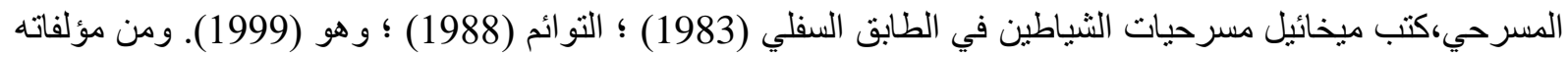

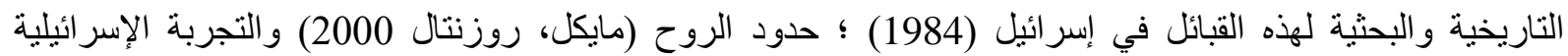

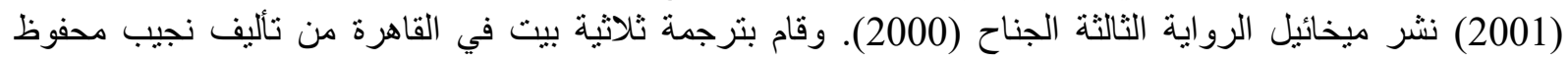

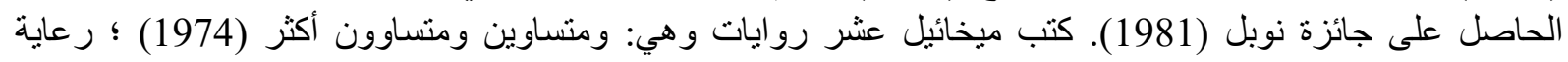

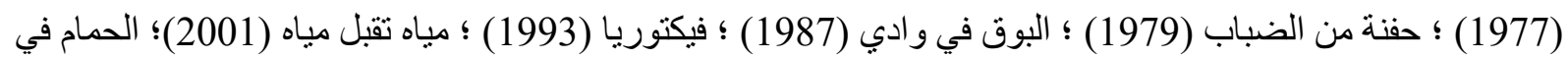

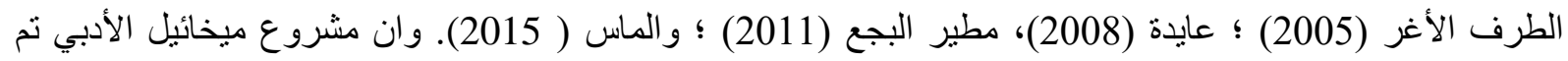

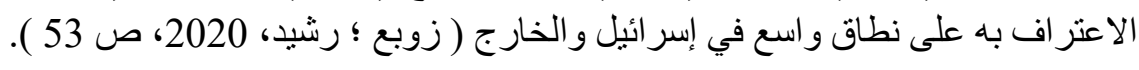

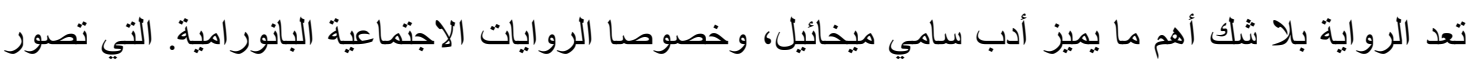

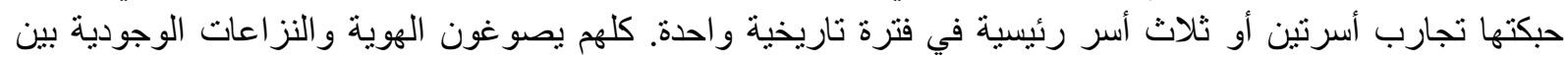

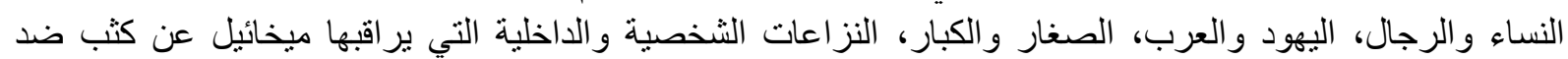

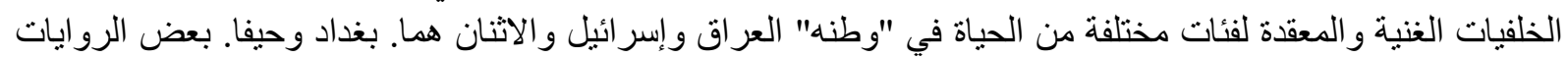

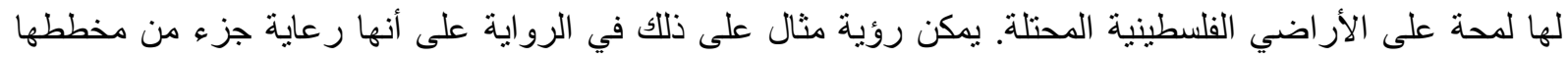

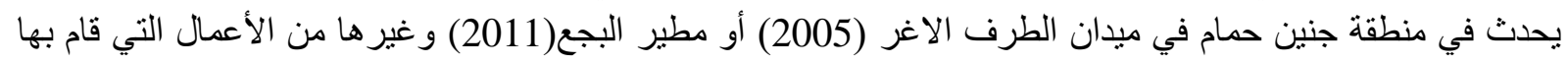
ميخائيل.

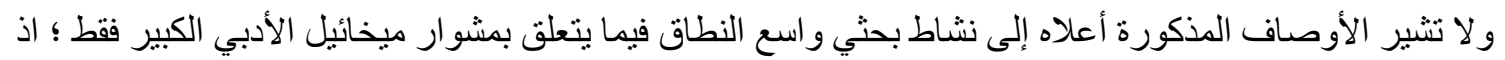

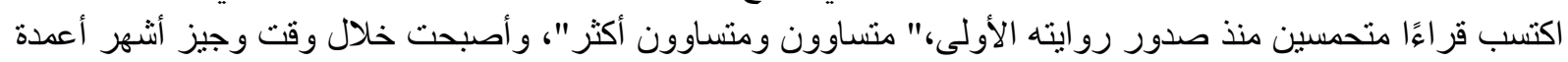

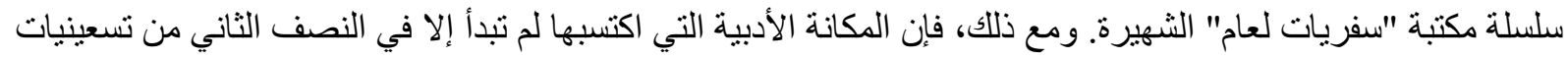

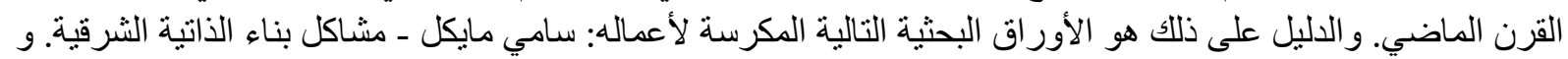

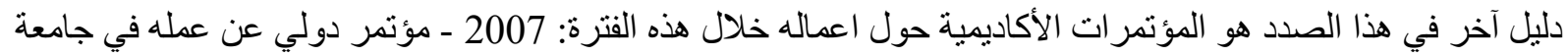

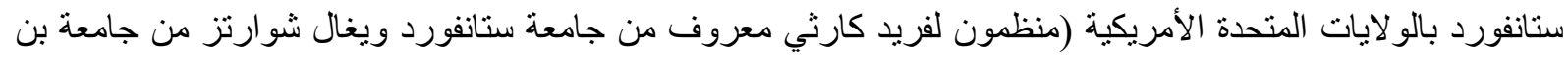

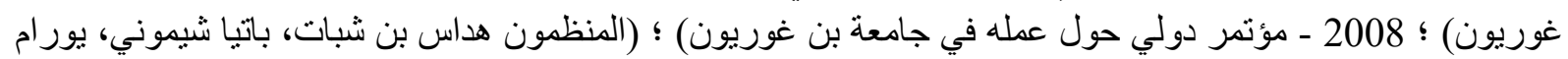

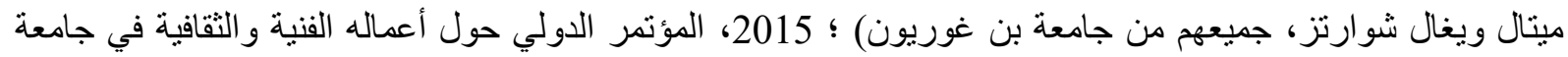

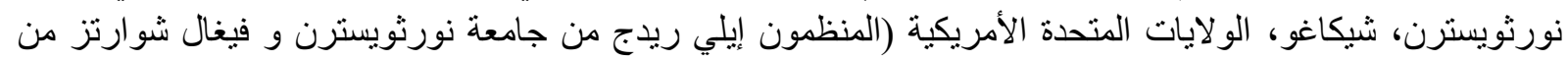


جامعة بن غوريون).انتخب سامي مايكل عضوا فخريا في أكاديمية اللغة العربية (2008) ويشغل منصب رئيس جمعية الحقوق المدنية في إسر ائيل منذ عام 2001. (Rashed A. M.-2., 2018)

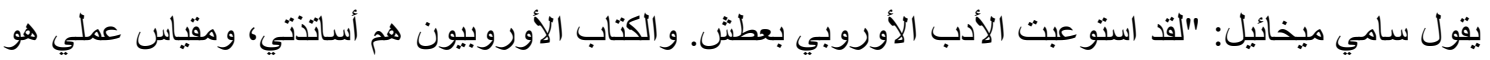

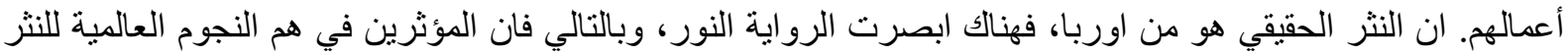

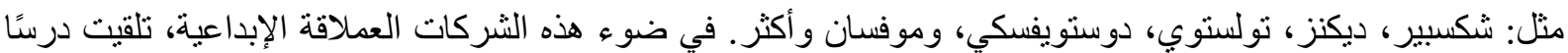

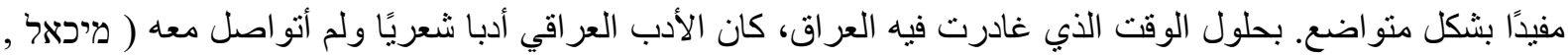

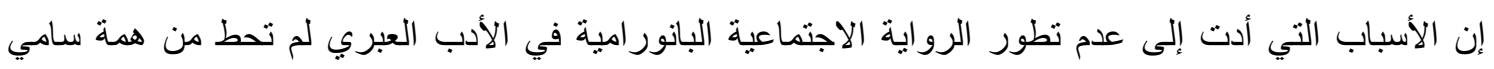

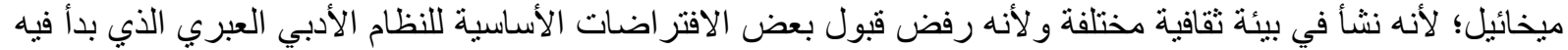

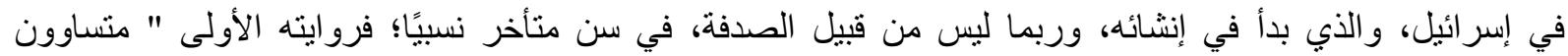
ومتساوون أكثر قد صدرت عام 1974، وهو ابن الثنائه وربما لينة والاربعين.(שקד, 1989 )

\section{المكان في روايات سامي ميخائيل}

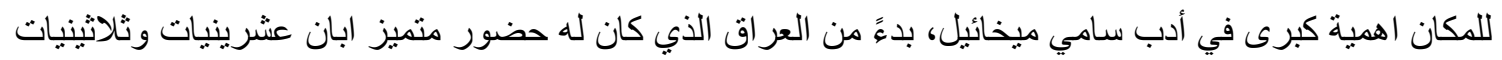

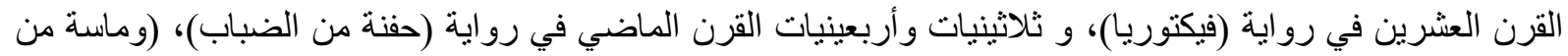

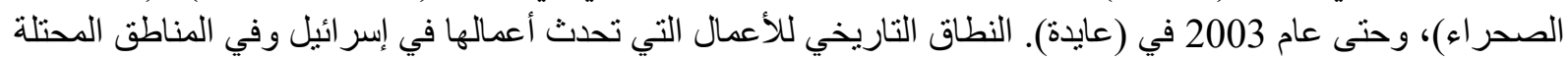

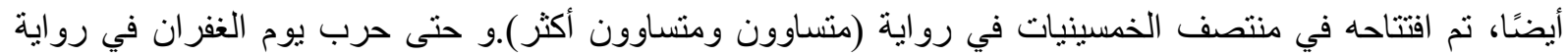

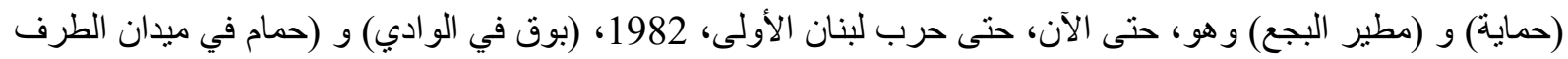

ان روايات ميخائيل هي بلا شك مجموعة كبيرة و غنية تمنحه مكانة بارزة في الفريق الثرقي للأدب الإسر ائيلي.

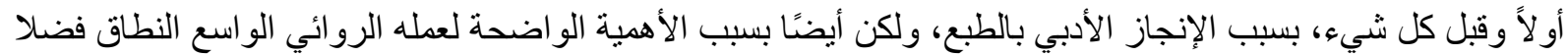

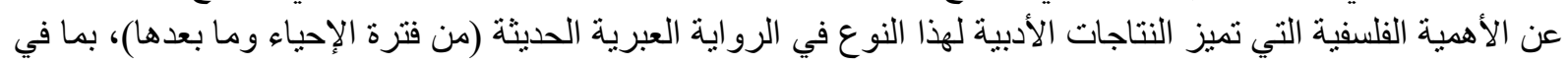
ذلك الخيال الإسر ائيلي.

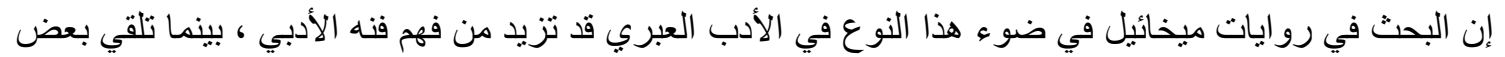

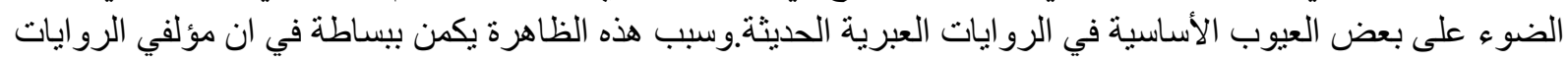

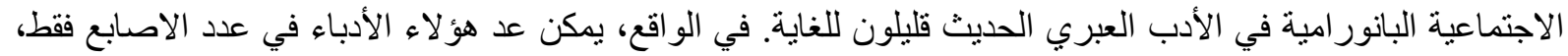

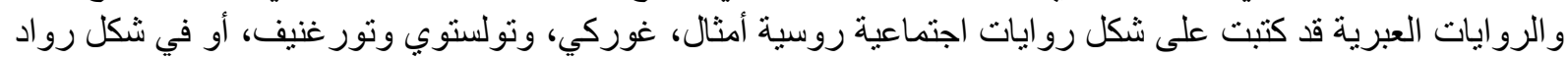

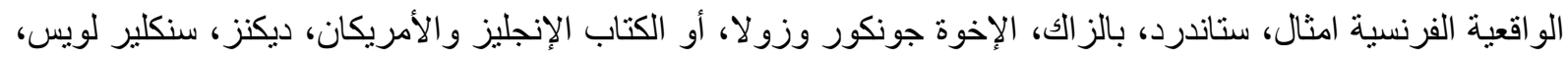

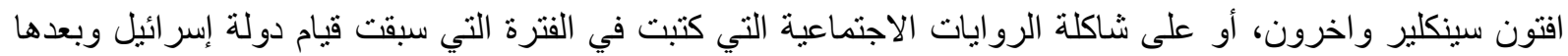

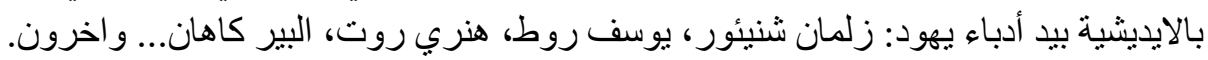

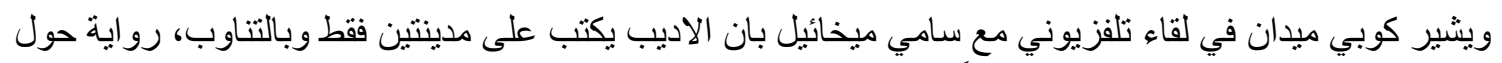

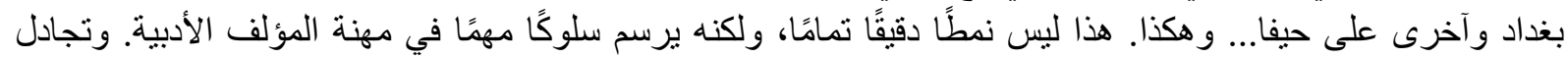

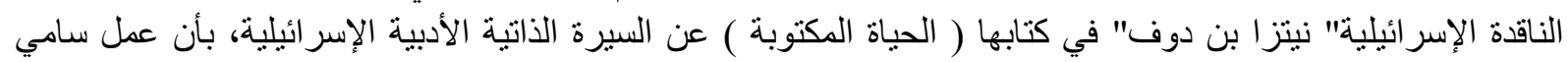

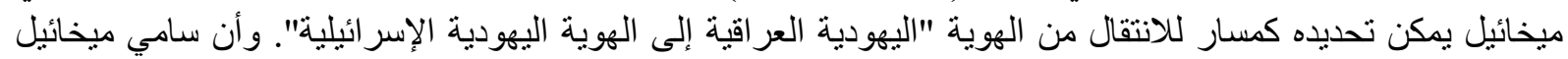

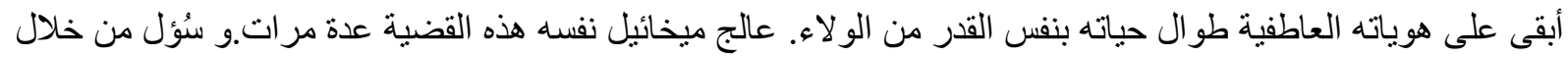

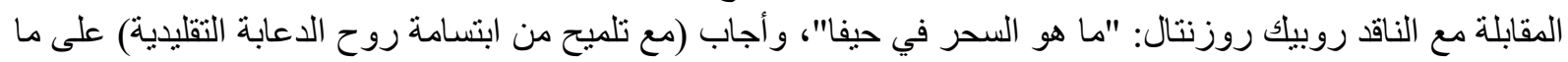

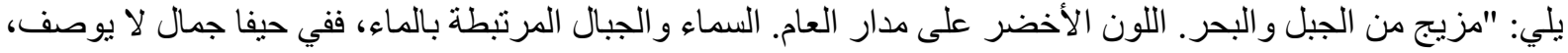

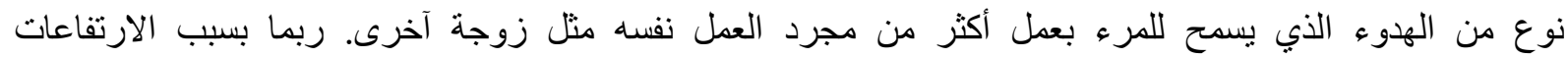

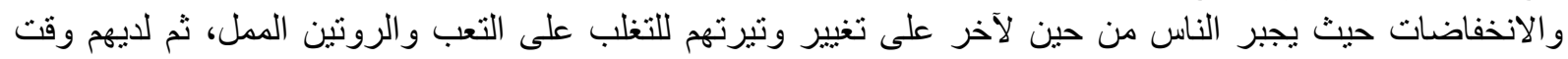

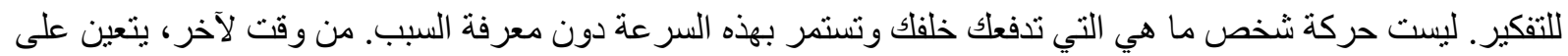

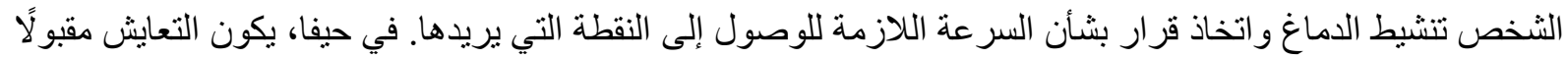

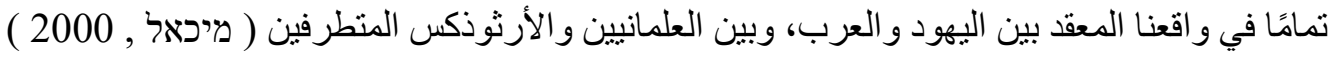


ورفض ميخائيل، متبوعًا بكتاب آخرين، رفض بشدة "طلب التقليد". مثل اهارون أبلفيلد، الذي رفض أيضًا هذا هذا

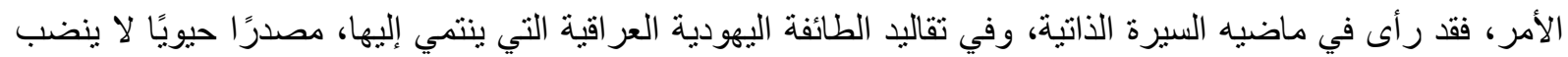

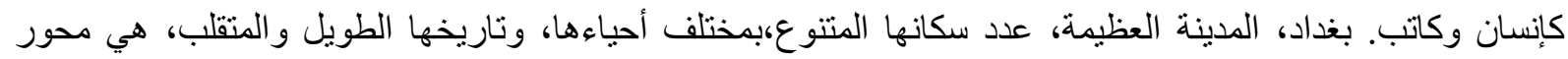
مركزي في الكثير من نتاجات ميخائيل الأدبية (Rashed A. M., 2020)

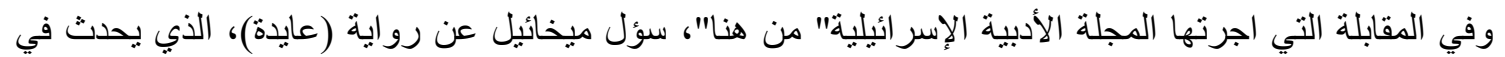

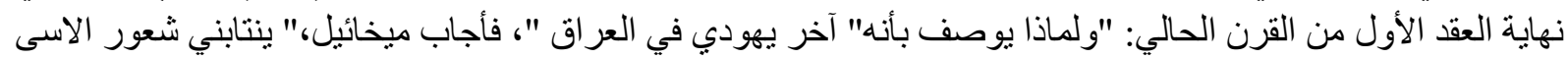

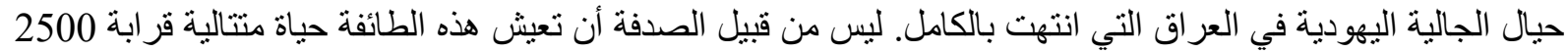

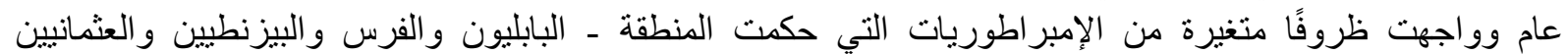

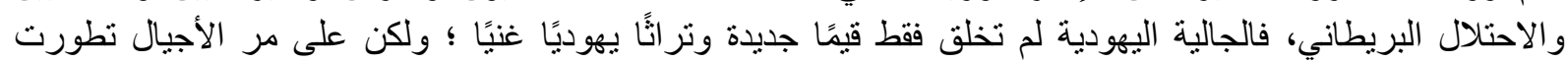

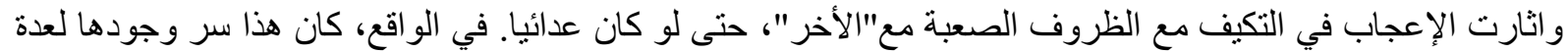

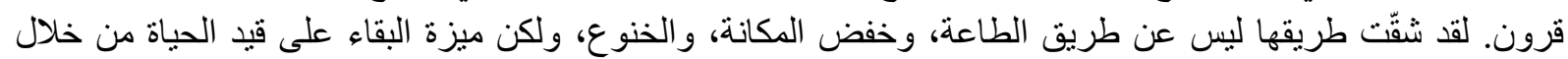

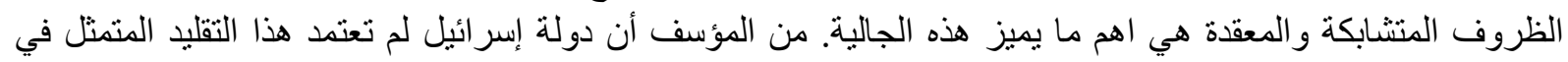

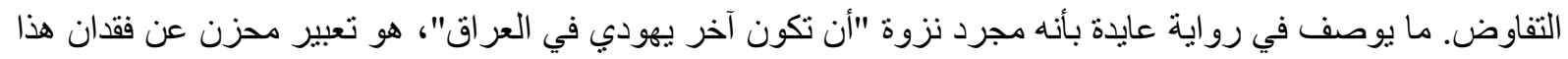
التراث في الثرق الأوسط. ( מיכאל , 2000 ) ماندة بانه

ويضيف قائلا: ابصرت عبناي على هذا التقسيم الطبقي الصعب: فكان هناك فقر اء ايضا ايضا في وسط الطائفة اليهودية

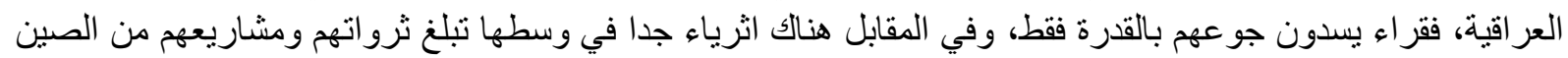

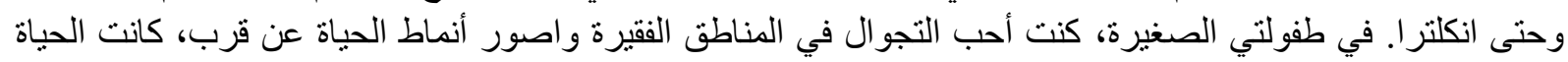

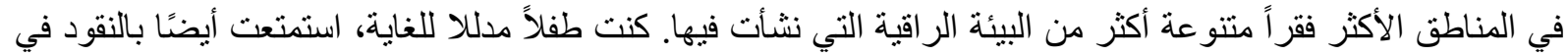

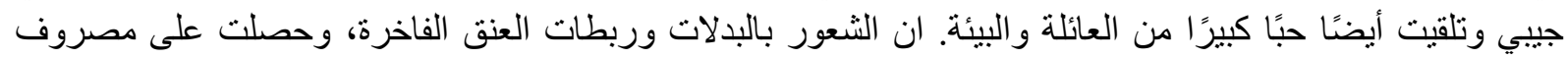

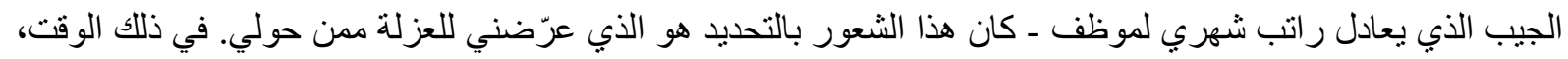

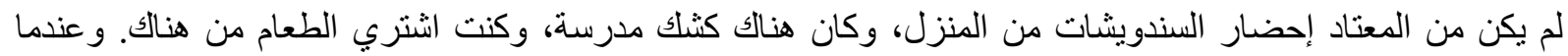

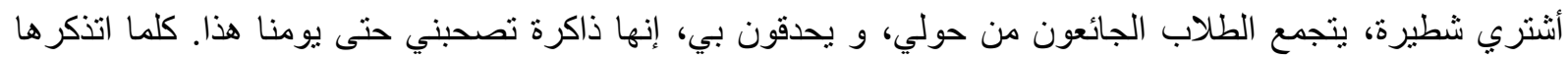

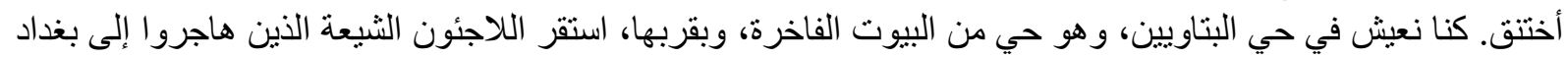

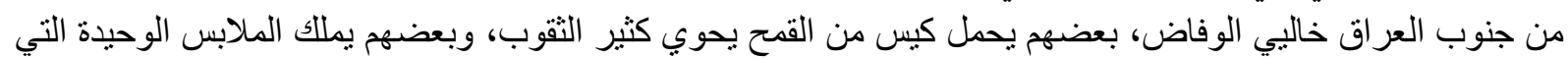

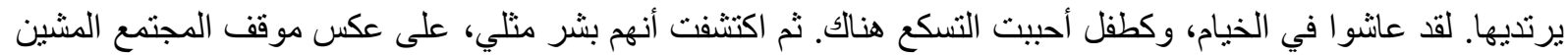

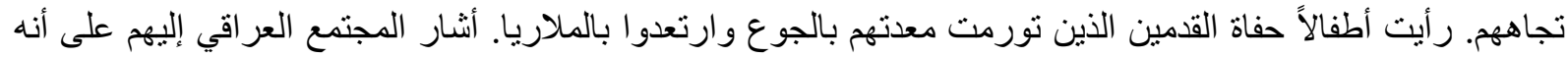

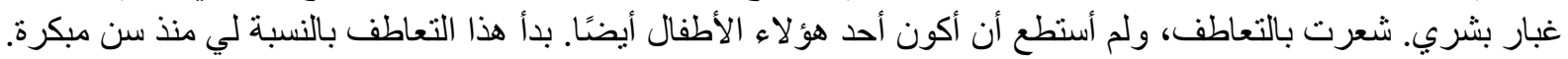

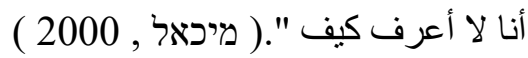

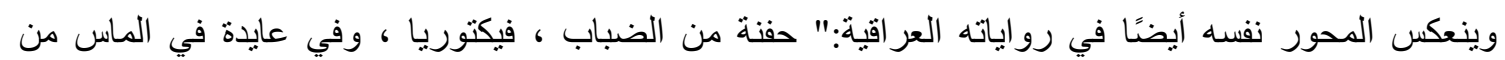

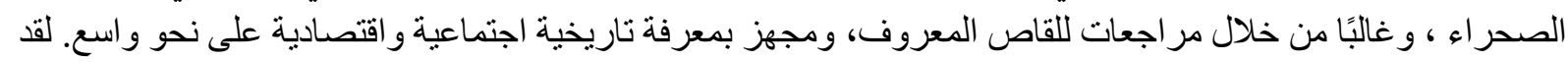

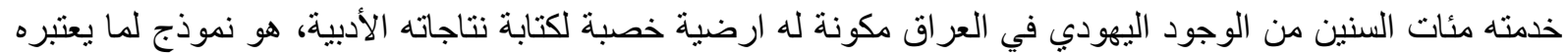

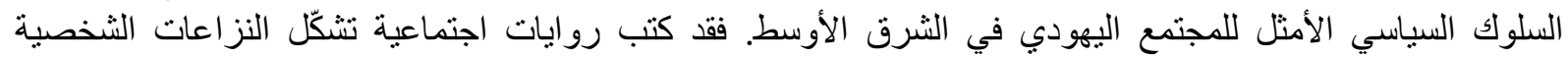

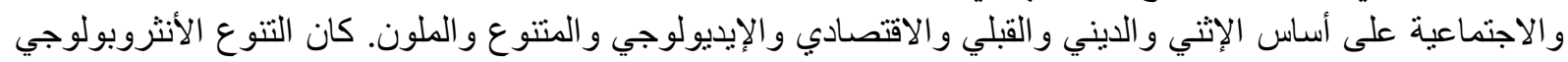

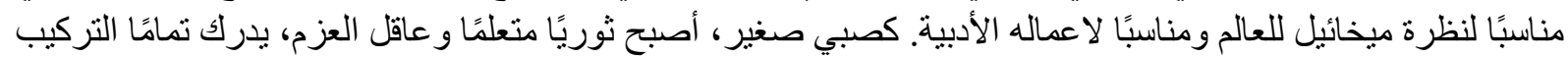

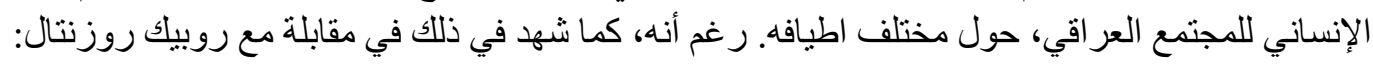

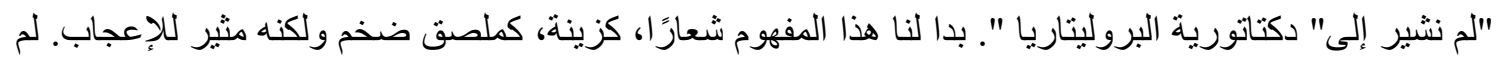

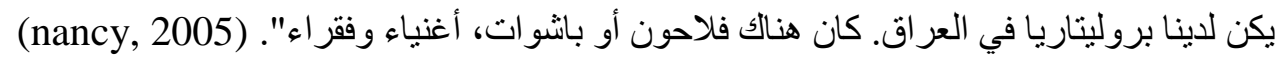

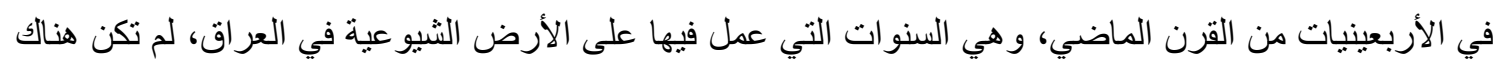

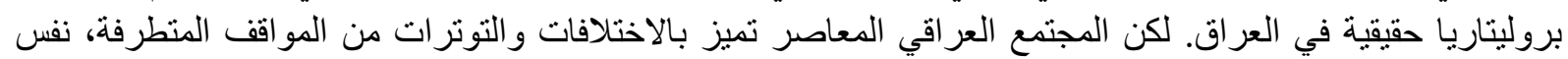

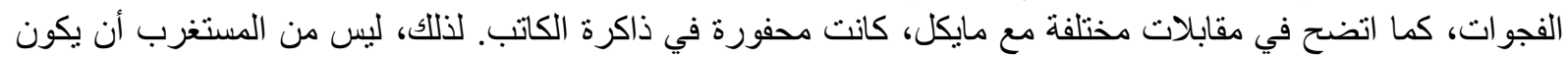

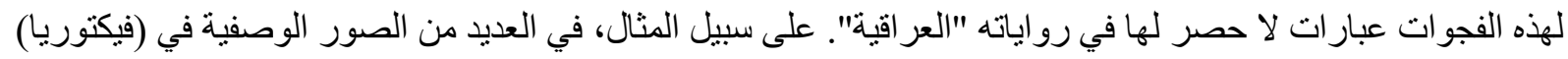

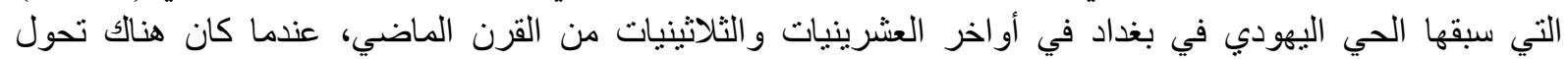
ديمغر افي جذري لجميع أبطال هذه الرواية الر ائعة. غالبًا ما يتم تصميم هذه الأوصاف بانيات باستخدام تقنية التقريب التدريجي. 
نتعرف أولاً على السياق الثقافي والتاريخي الأوسع، وبعد ذلك يقودنا الراوي في حركة مقاسة إلى الحي اليهودي في

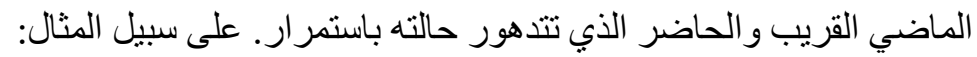

"העיר הגדולה, שהתפתחה מכפר נידח בשולי הממלכה הסאסנית, חבה הרבה לאבותיה של ויקטוריה.

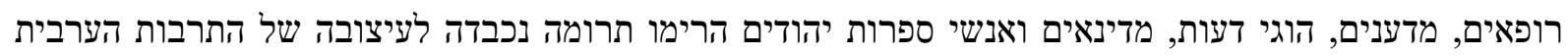

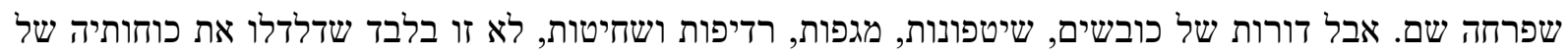

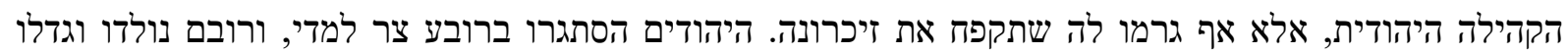

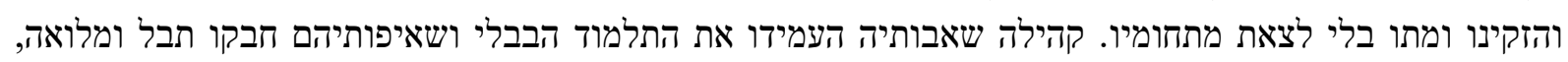

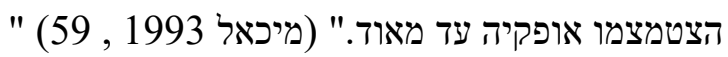

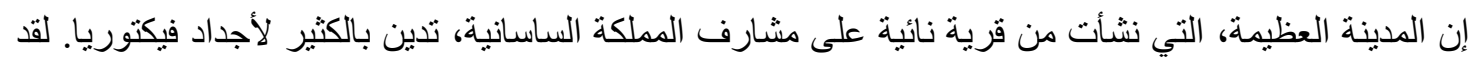

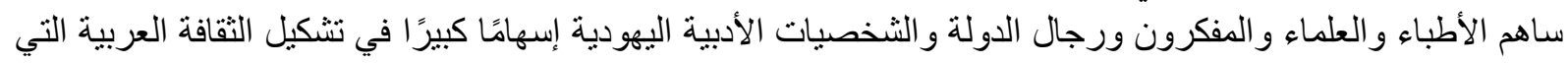

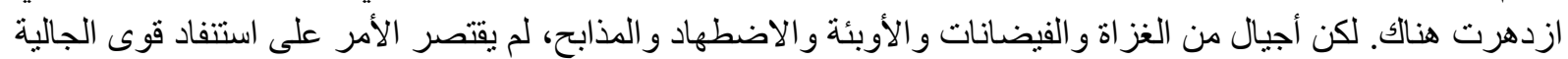

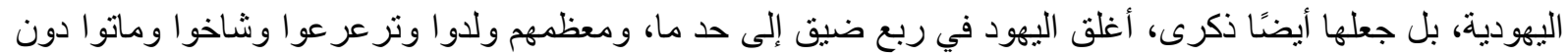

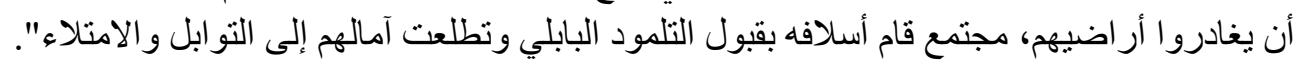

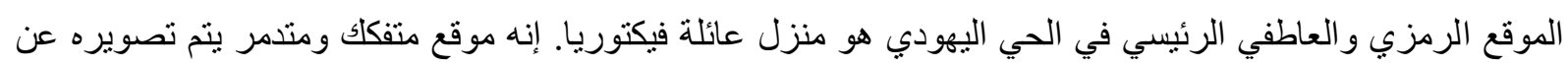

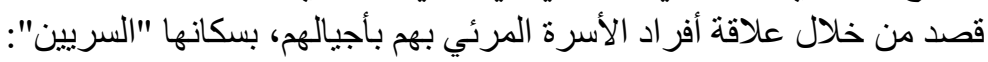

"נמלים, פרעושים, תולעים, תיקנים, עקרבים, חיפושיות, עכברים ונחשים [...]":

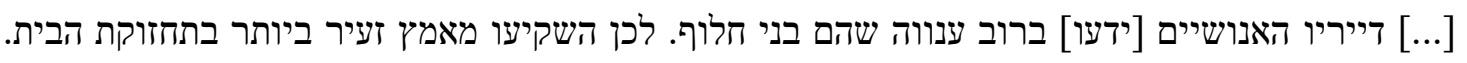

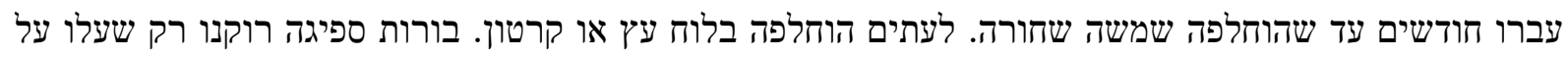

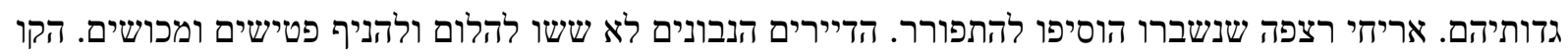

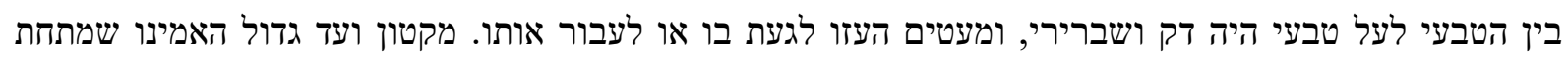

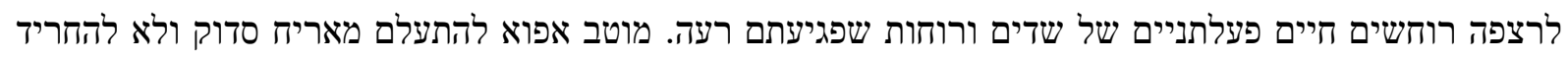

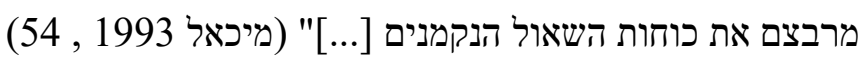

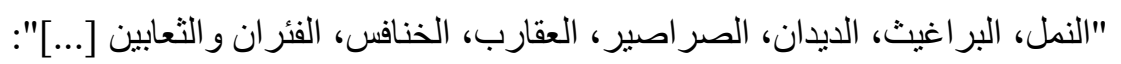

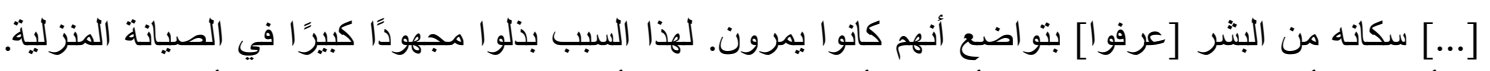

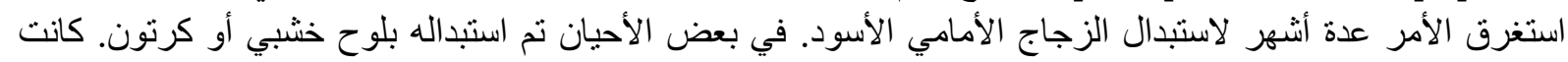

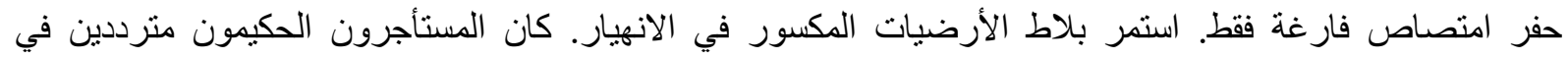

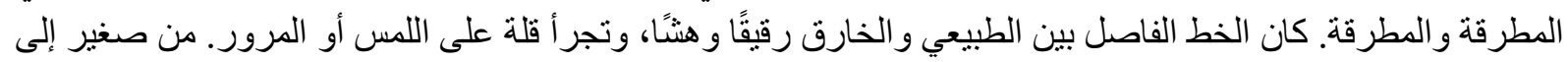

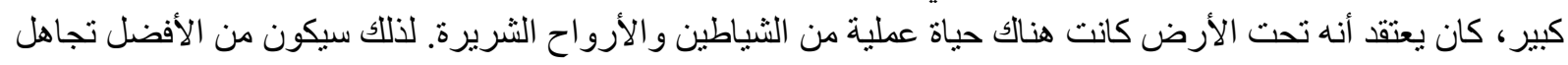

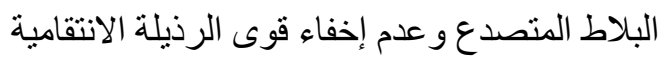

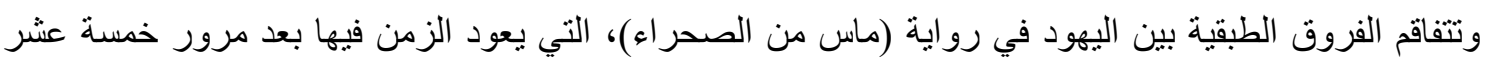

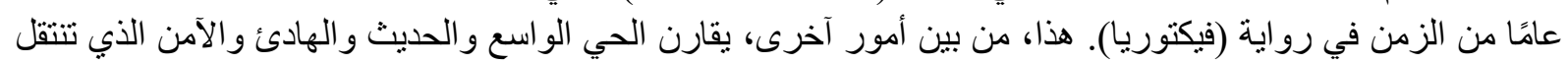

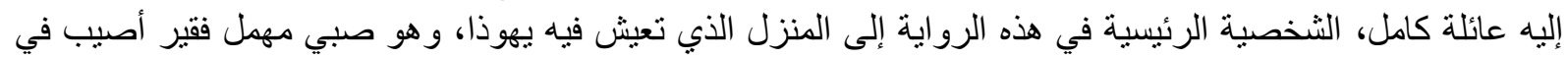

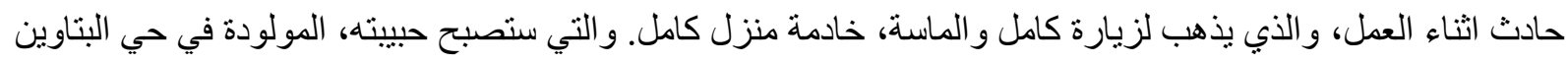

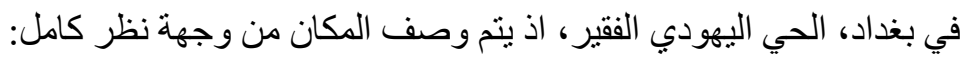

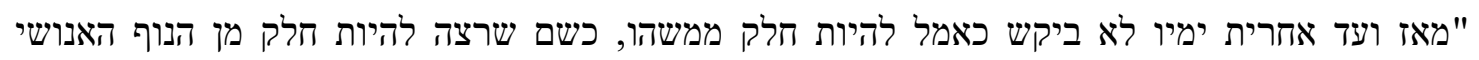

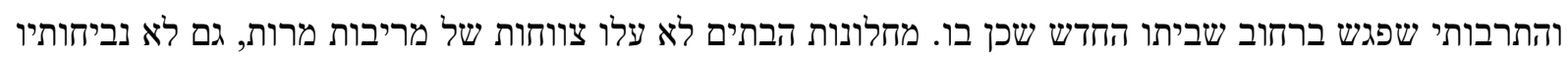

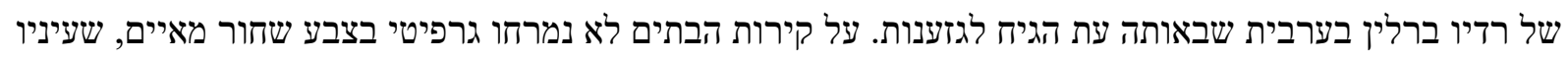

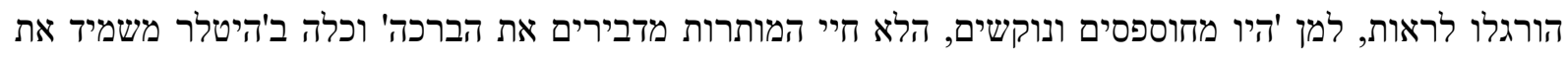
החיידקים' [....

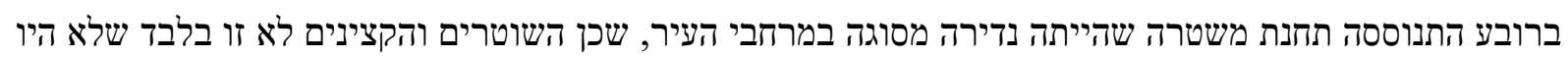

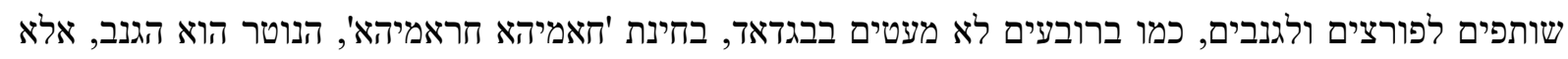


שלכלל האוכלוסייה המעורבת - מוסלמים, יהודים ונוצרים - העניקו השוטרים תחושת ביטחון, שעמדה במבחן

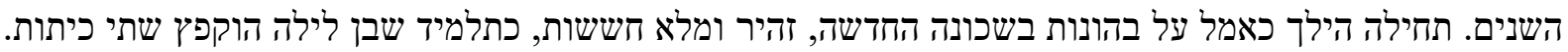
המעבר משוק חנווני לרובע החדש שהלך והתרחב, הלך ושגשג, היה כרוך בהלם תרבותי." (מיכאל 2015 , 178)"

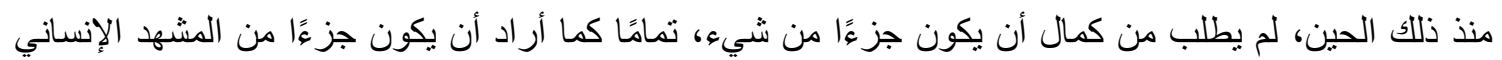

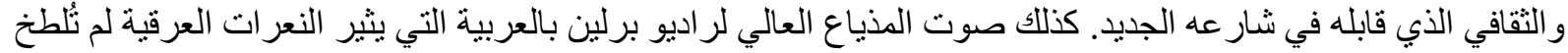

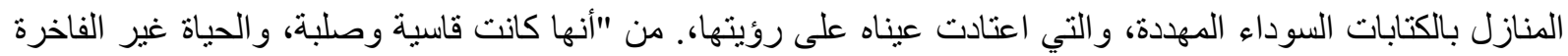

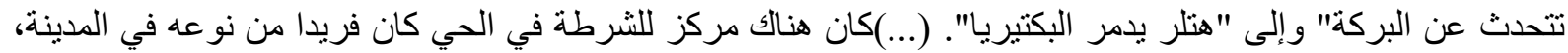

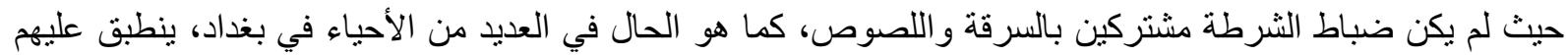

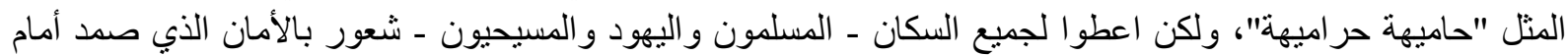

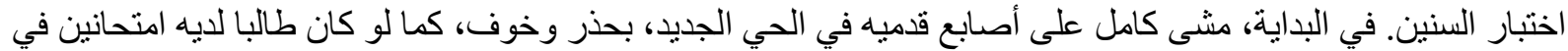
اليوم التالي. إن التحول من سوق البقالة إلى منطقة جديدة مزدهرة وحديثة فئنة ينطوي على صلى صدمة ثقافية".

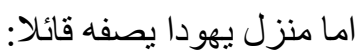

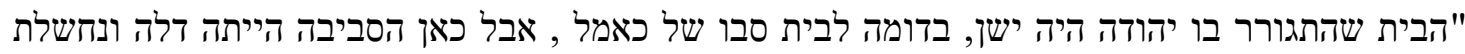

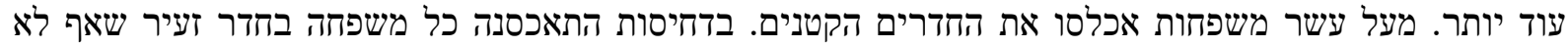

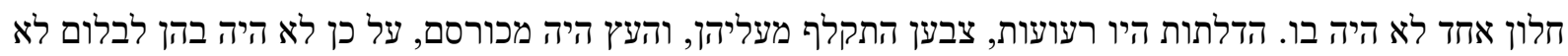
את הרוח ולא את העכברים שעל נקלה הסתננו פנימה [...]. משלא נענו מפורשות, הדפה אלמאסה את הדלת המתפוררת. משב נעלף של צואה וזיעה הכה את הנחיריים.

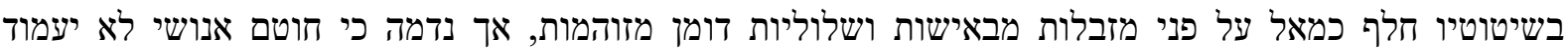

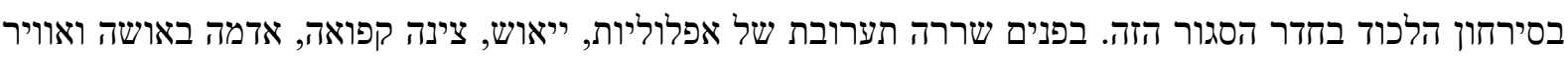
מעופש שעומדת בו צחנה של הפרשות אדם שצרבו את העיניים מעוצמת חריפות הריח[...] (מיכאל 2015 , -220

كان المنزل الذي كان يعيش فيه يهوذا قديمًا، مثل منزل جد كامل، لكن الحي هنا كان هزيلًا ومهدمًا. استو عبت أكثر

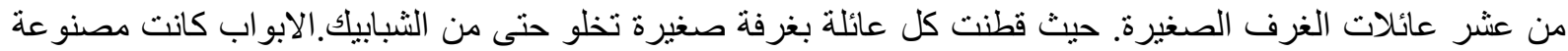

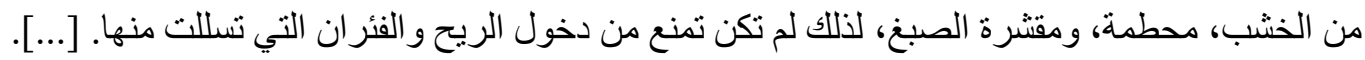

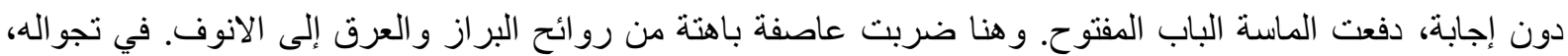

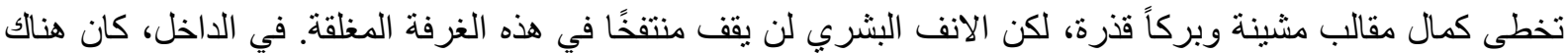

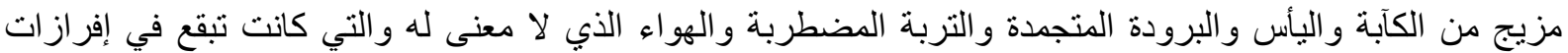
الإنسان التي أحرقت العيون بكثافة الرائحة النفاذة. [...].

\section{الفوارق الطبقية في نتاجات سامي ميخائيل}

يصف ميخائيل في روايتي " فيكتوريا وماس من الصحراء" الفوارق الطبقية والفقر والغنى في وسط الطائفة اليهودية، اما في روايتي " عايدة وحفنة من الضباب " فقد وصف الفو ارق الطبقية والفقر و الغني بين المسلمين و المسيحيين.

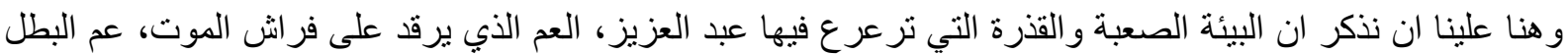

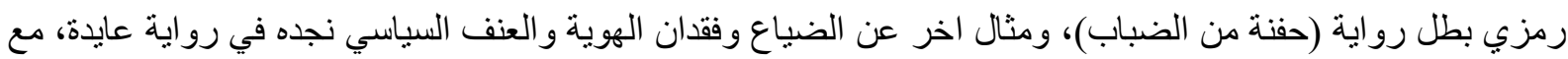
بطلة الرواية التي عانت الاضطهاد و القمع من قبل افر اد النظام السابق. ومن الناحية الايدولوجية السياسية يشير الناقد جرشون شيكيد بضرورة ادر اج امتتاع ميخائيل بقبول فكرة "الأدب التئ

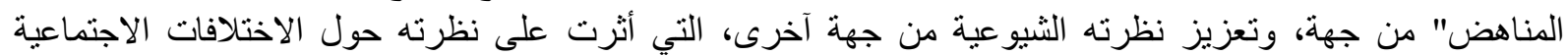
و العرقية والاقتصادية، في السياق الذي أمامنا ـ ضمن الثروط الثيز اللازمة لكتابة الروايات الاجتماعية البانور امية التي مشهدها

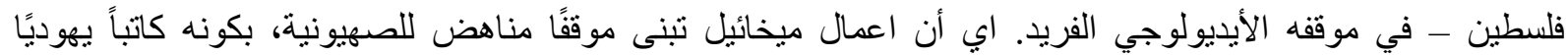

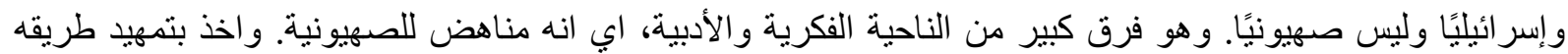

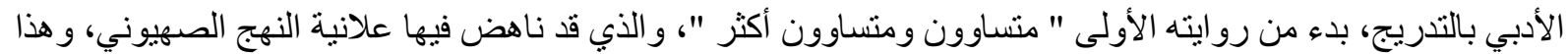

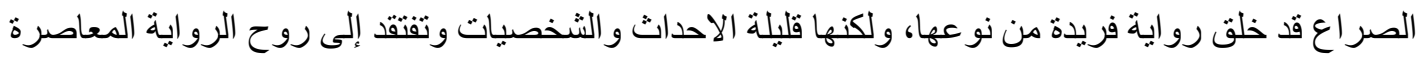




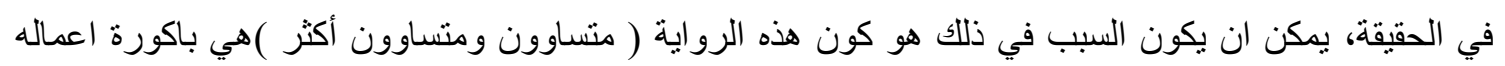

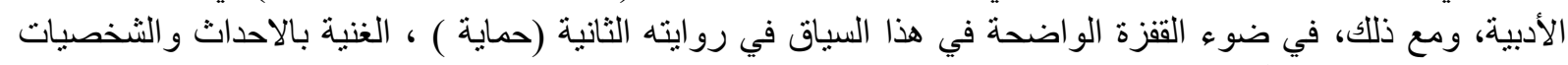

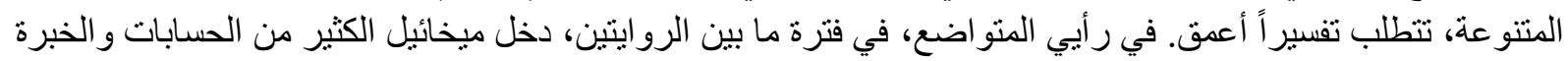

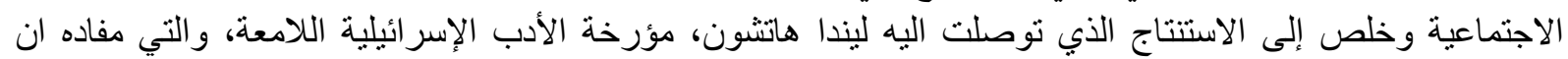

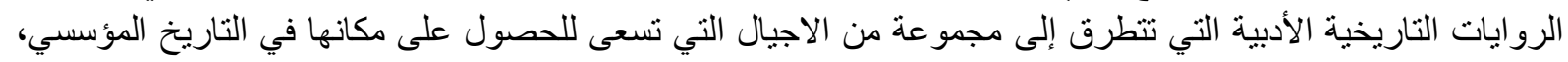

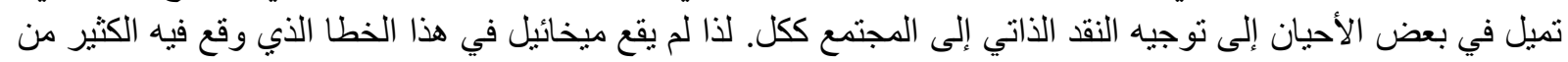

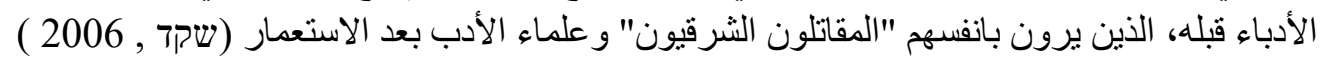

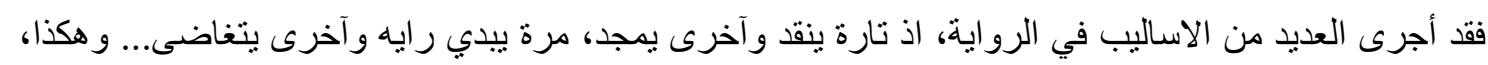

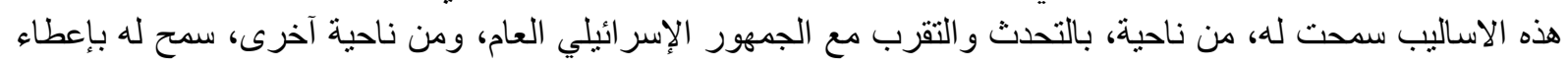
نصائح شفهية وغنية ومتنوعة وجديرة بالثقة للجماعات الإثنية والاجتماعية المستبعدة من الخطاب الأبناب الأبي في إسر ائيل

.(Rashed A. M.-2., 2018)

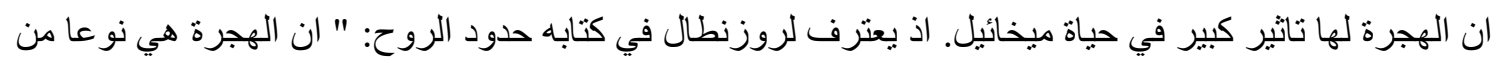

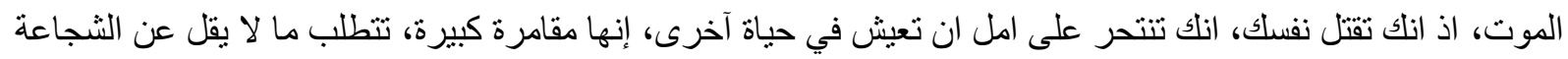

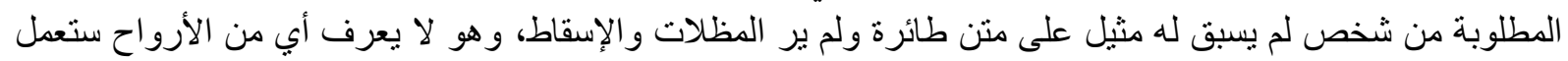

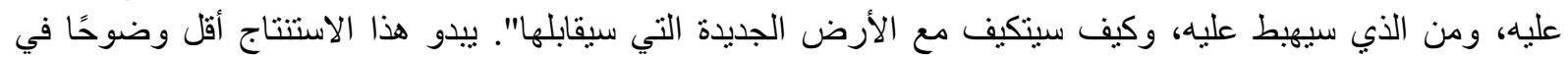

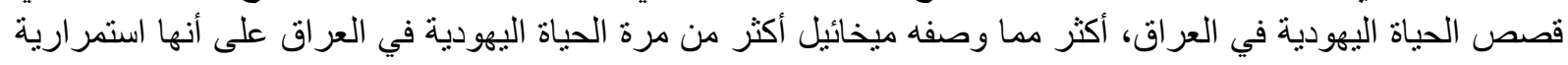

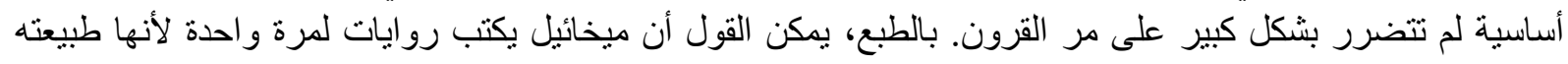

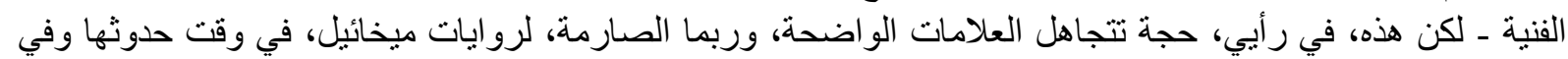
الموقع الجغر افي. (שקד , 2006 (

صمم ميخائيل كل هذا التنوع الإنساني الواسع من خلال الإطار الأيديولوجي الذي اكتسبه في شبابه في العراق، ثن

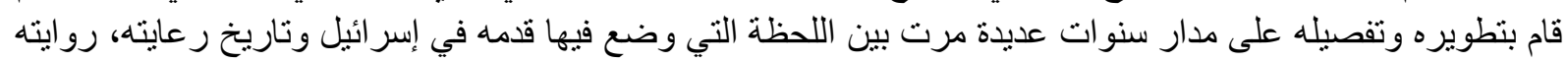

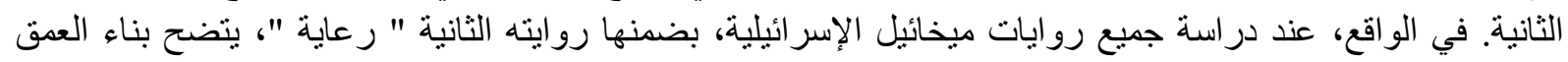

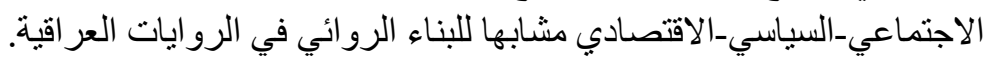

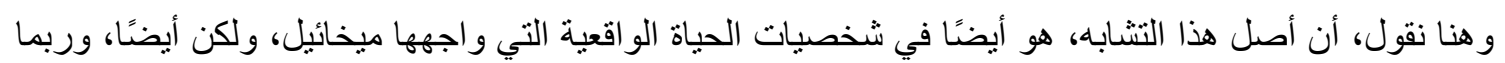

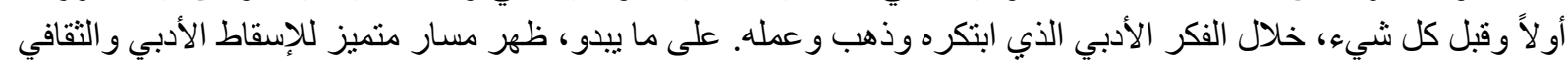

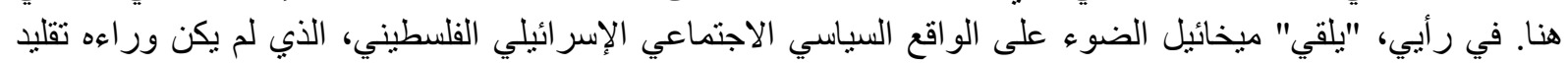

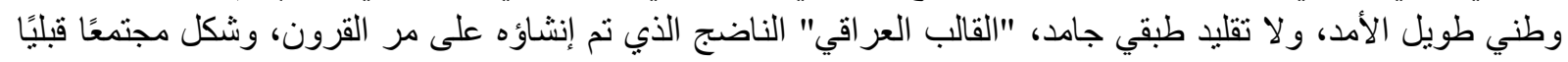

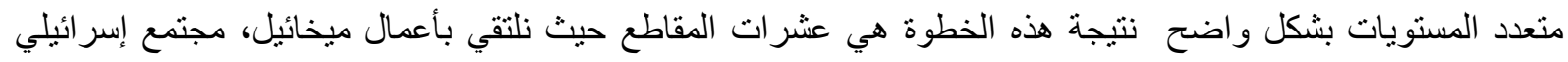

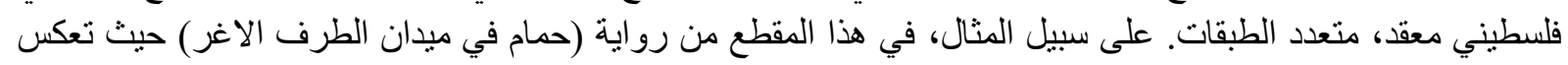

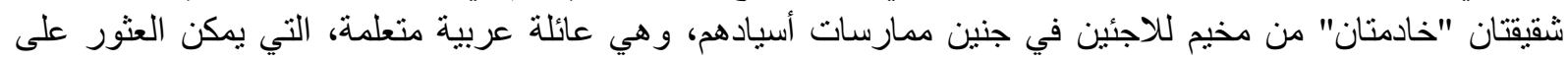
الكثير منها في الأعمال الدر امية الاجتماعية البريطانية:

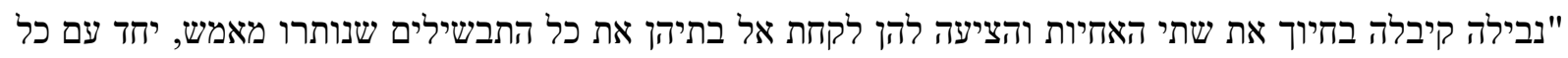

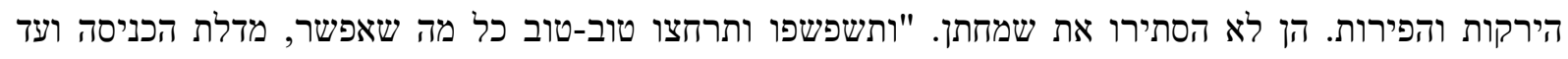

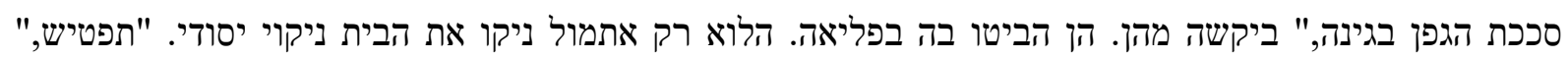

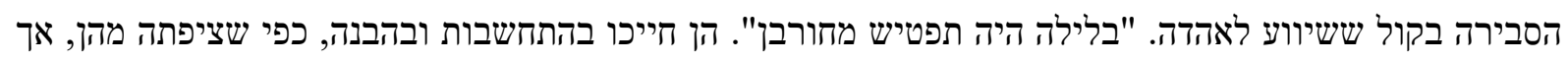

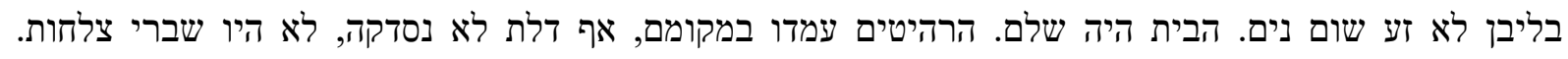

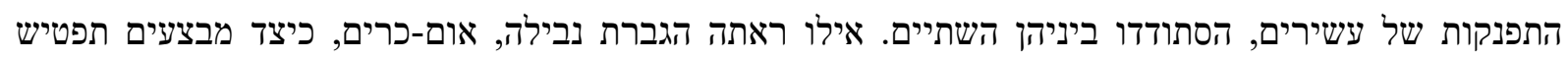

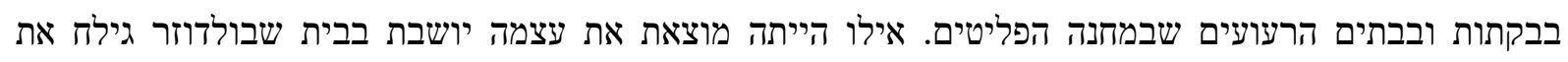

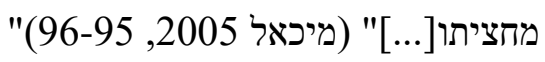




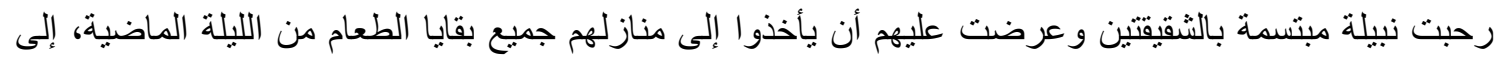

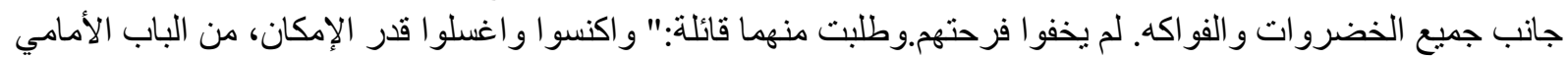

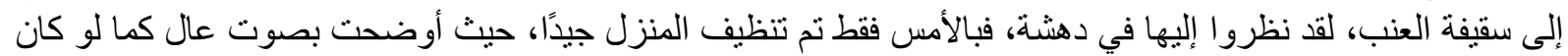

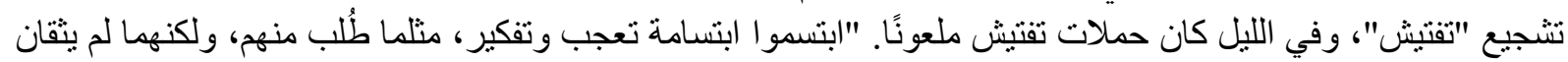

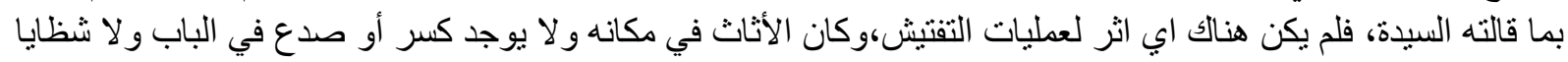

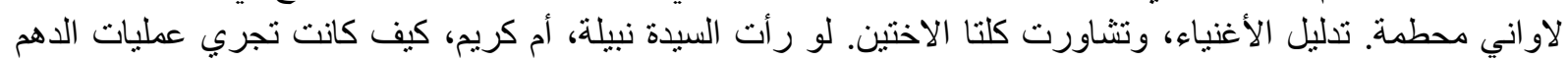

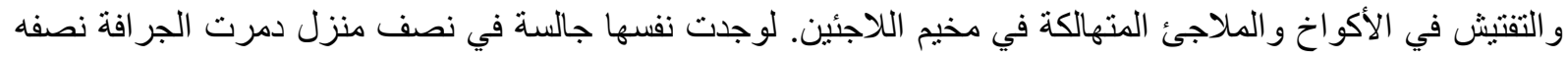
الاخر ".

ويضاف سبب اختيار الكتابة بالعبرية وتاثير الروايات العالمية إلى قائمة الأسباب التي مكنت سامي ميخائيل من

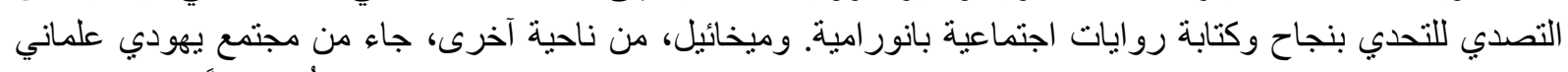

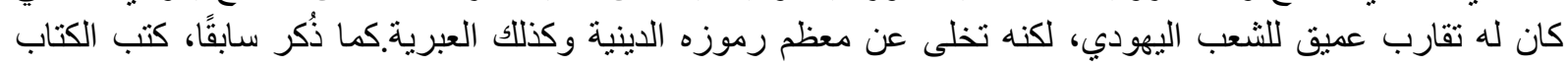

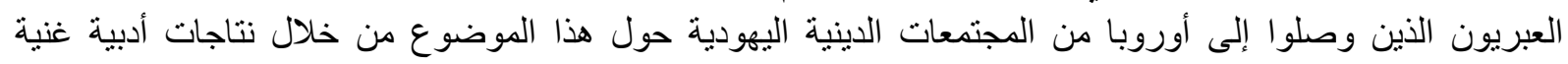

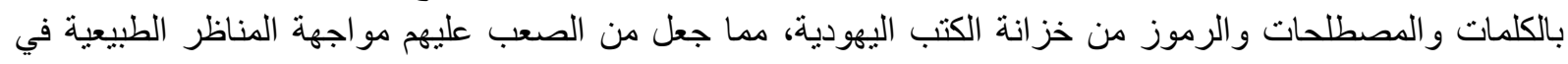
البلاد (أمثلة كلاسيكية: برينر و عجنون) (מיכאל , 2000 )

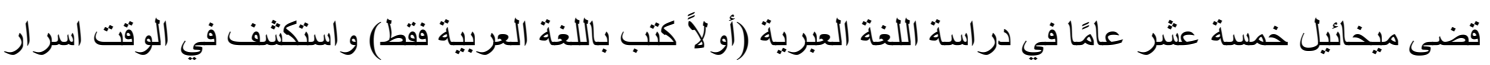

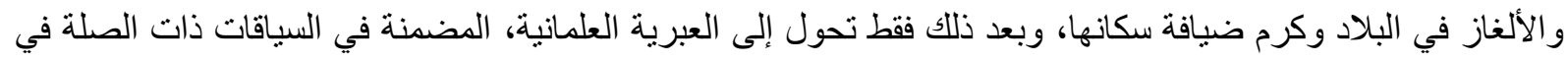

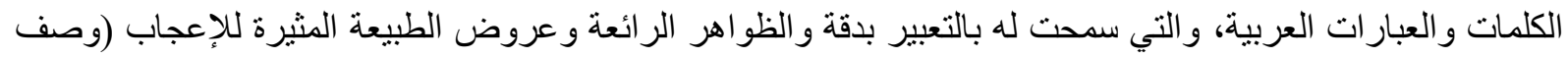

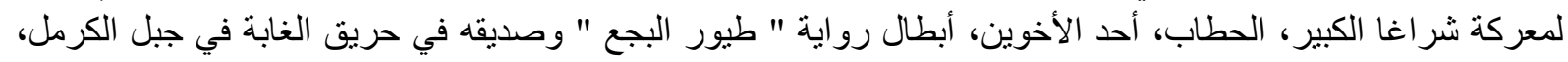

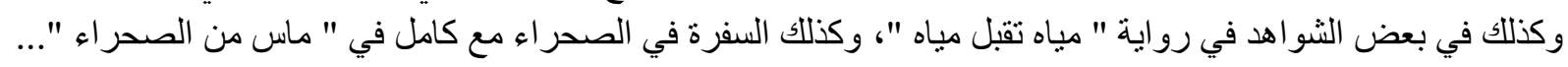

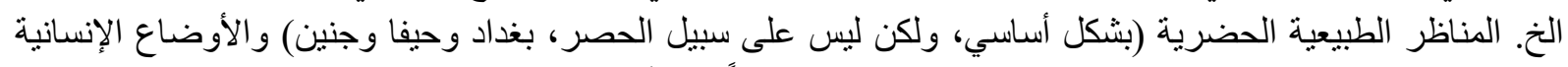

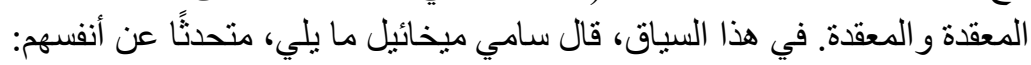

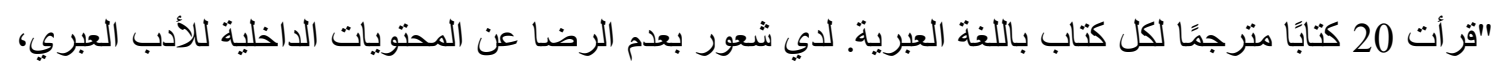

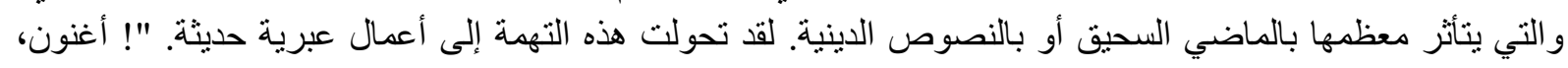
الذي أصبح منارة الأدب العبري، وليس برينر وتشرنيخوفسكي، على سبيل المثال." (מיכאל , 2000 )

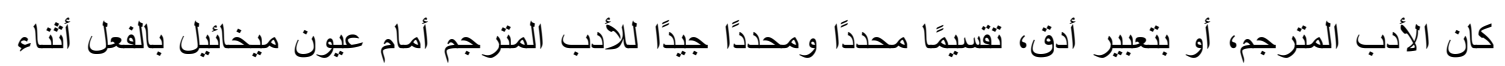

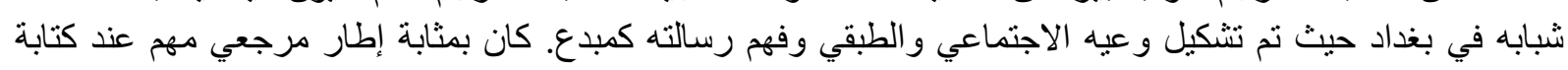
الروايات الاجتماعية:

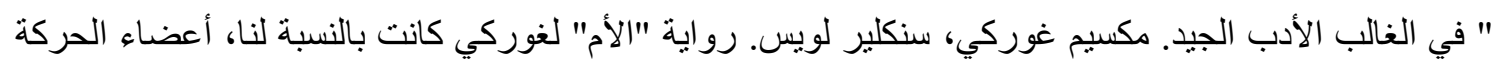

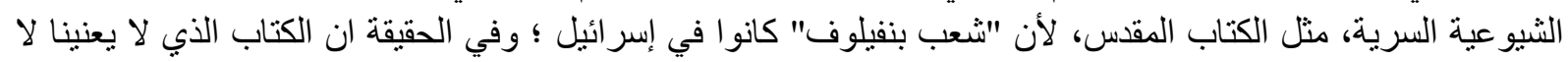

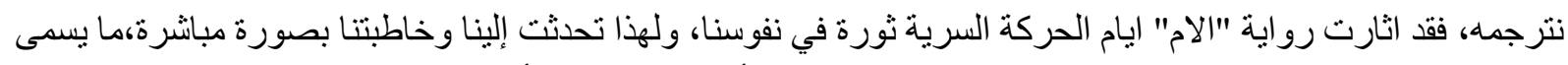

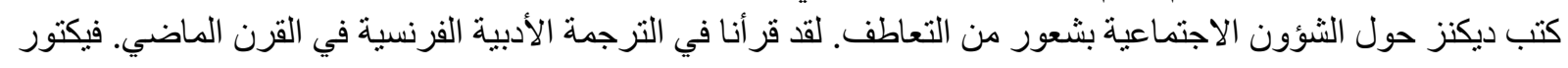

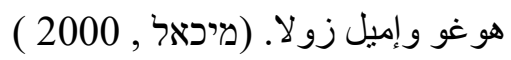

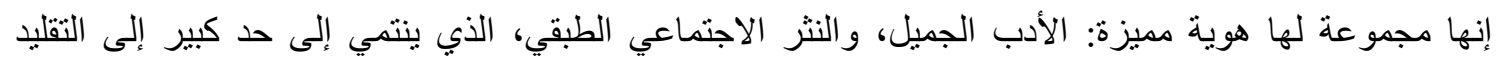

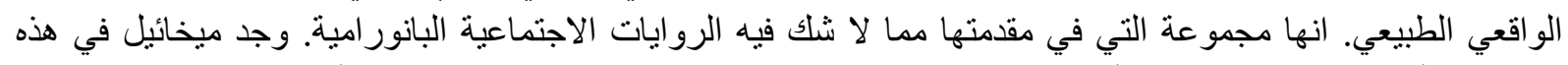

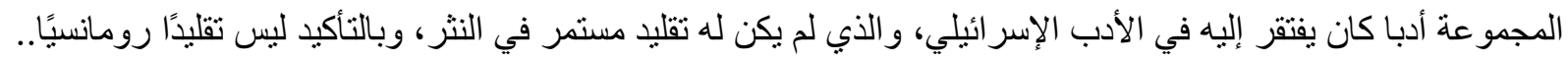

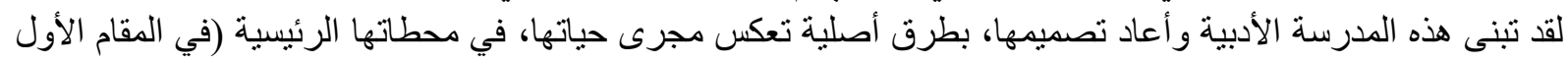

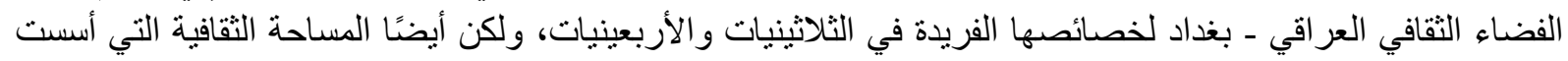

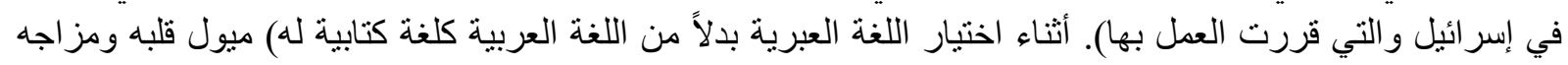

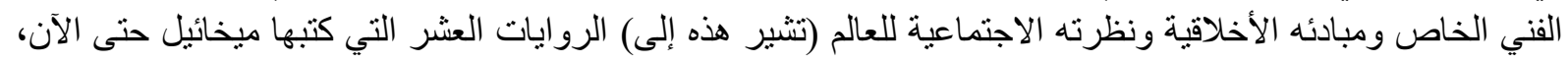

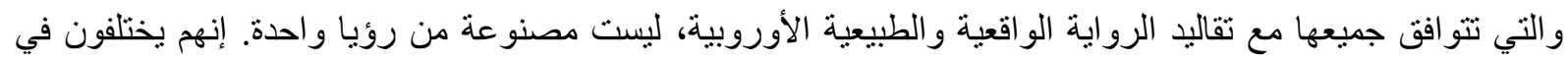

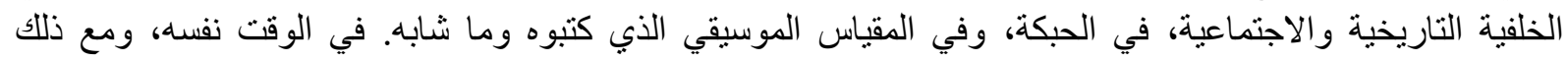

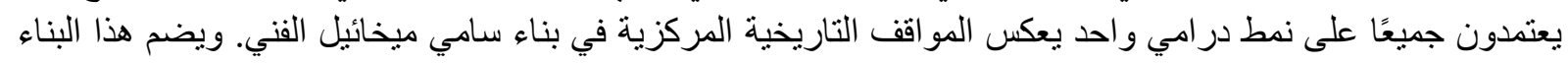


الروائي على محور أساسي للحبكة، الذي يحتوي على قصة قابلة للنطور، ومحوران اخران ثانويان، و التي تنسجم مع التح المحور المركزي وتحديد حدودها الاجتماعية والوجودية. (Rashed A. M.-2., 2018)

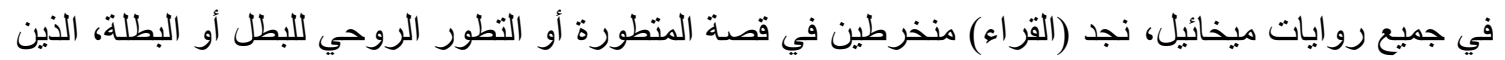

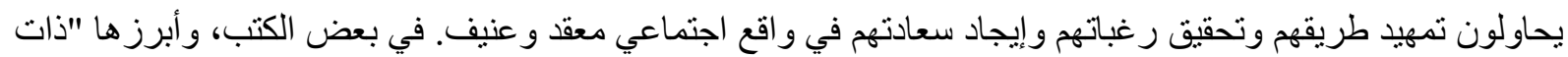

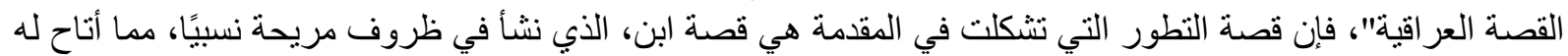

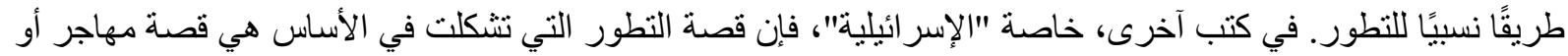

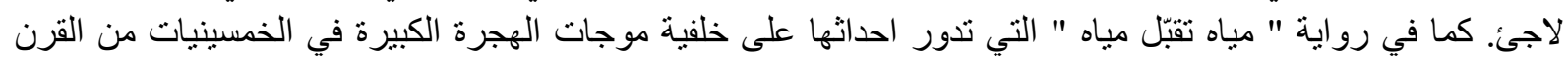

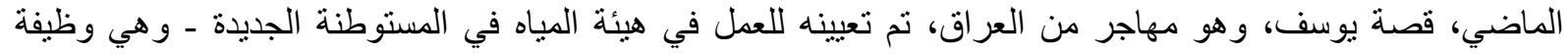

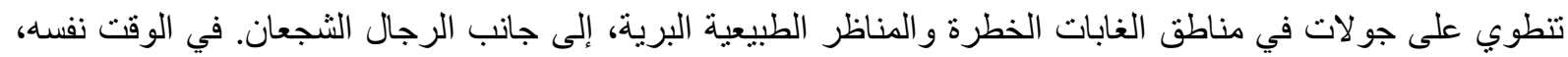

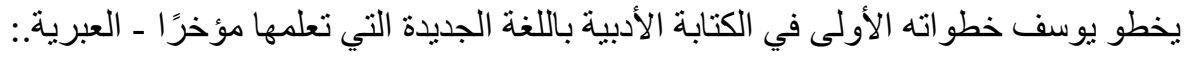

" יוסף ישב אל שולחן כתיבה צנוע יותר בירכתי הלשכה, שקוע בגירסה השלישית לפתיחת הרומן העברי

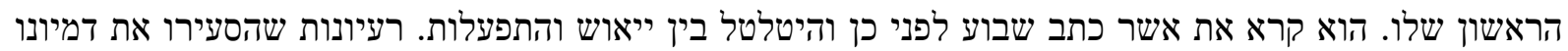
בשעתם היו מוטלים עתה לפניו על הנייר כיצורים מאכזבים לאחר ליפרי לידת נפל." ( מיכאל , 2001 )" جلس يوسف على طاولة أكثر نو اضعا في الجزء الخلفي من المكتب، منشغلا في النسخة الثالثة من افتتاحية روايته

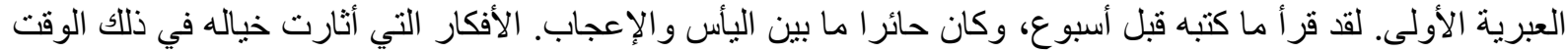

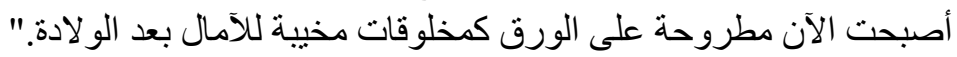

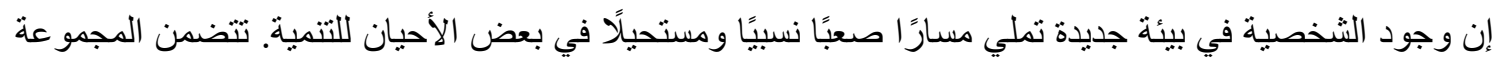

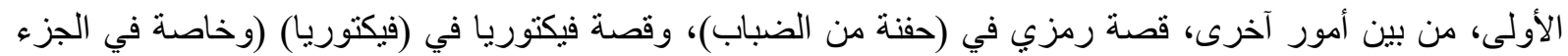

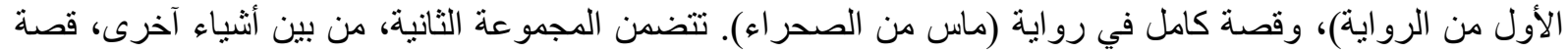

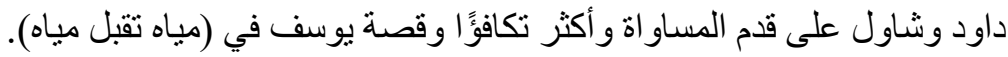

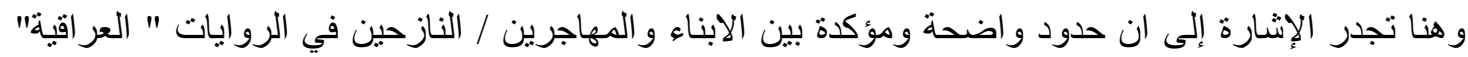

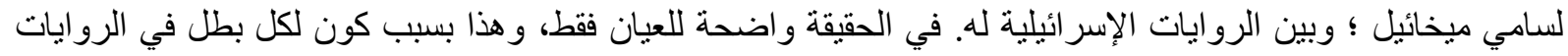

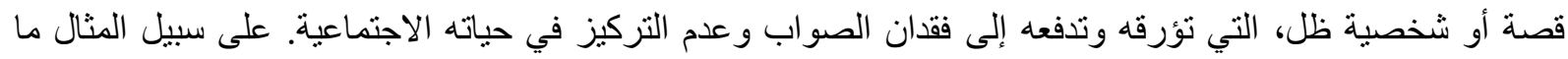

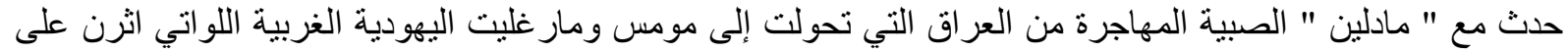

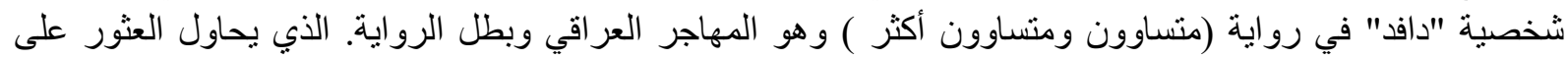

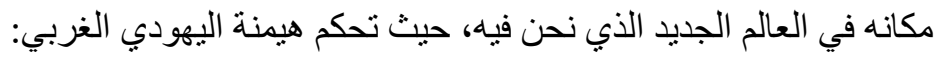

"אתה מבין, יא אבו-שאול, [...] העיקר - בתוך בניי עמי! שווה לכולם. הולך בראש זקוף, אה? אתה יודע מה זה -

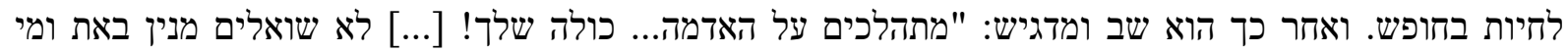

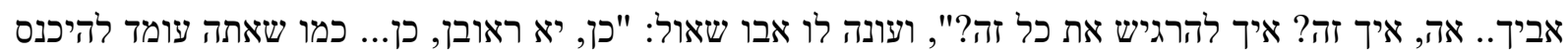

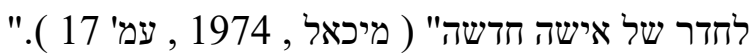

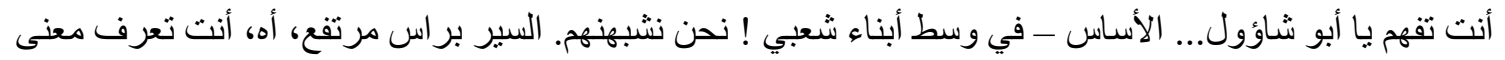

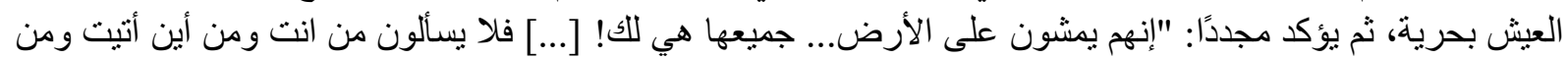

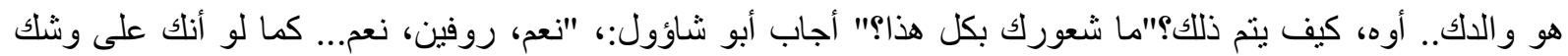
الدخول إلى غرفة امر أة جديدة."

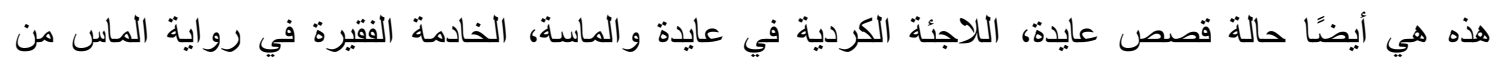

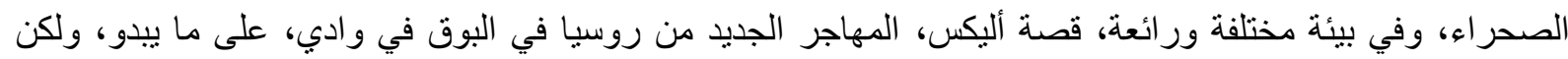

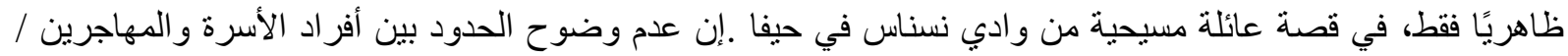

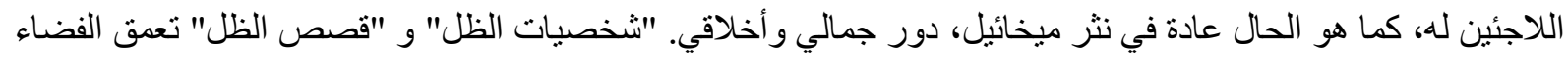

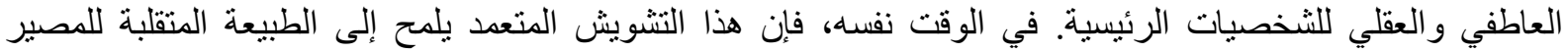

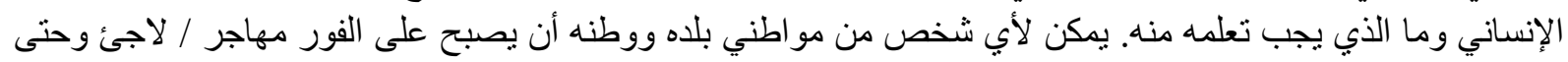
متجول بلا مأوى - و هذه حقيقة محددة تتطلب التو اضع و الألت التسامح. 
" אין לי ידידות וידידים ערבים. אני משתדלת להיות ישראלית יותר מן היהודים עצמם...ועכשיו יהודה עמיחי קרוב ללבי יותר מכל משורר ערבי"( מיכאל , 1987 , עמ' 5 ) "

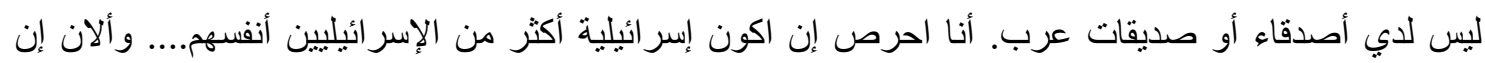

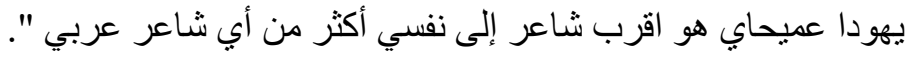
ان البناء الفني لرواية التشكيل تبرز واضحة في رواية " ماس من الصحر اء ".إنها رواية تمثل في الأساس صورة

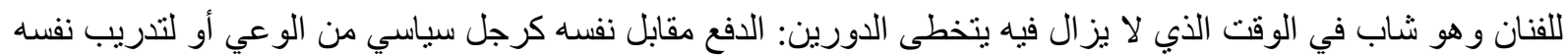

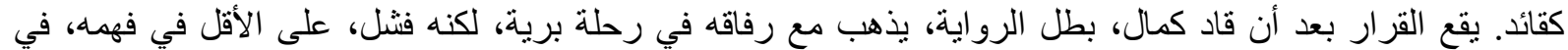
محاولته لإعادتهم بأمان إلى منز لهم .

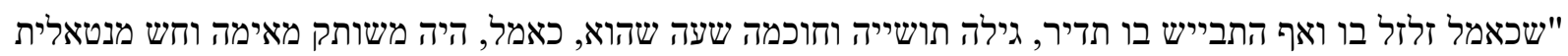

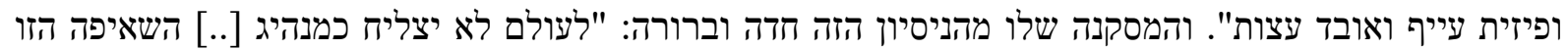

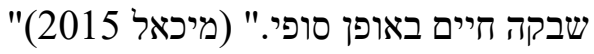

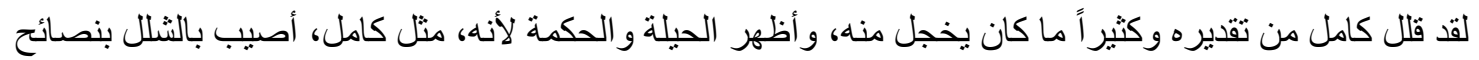

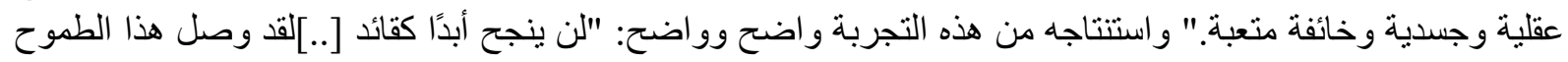
إلى نهايته ".

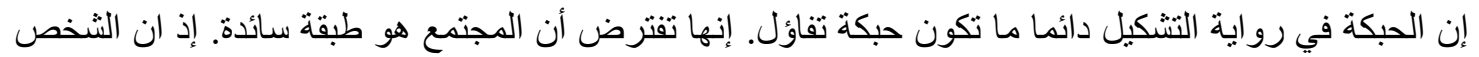

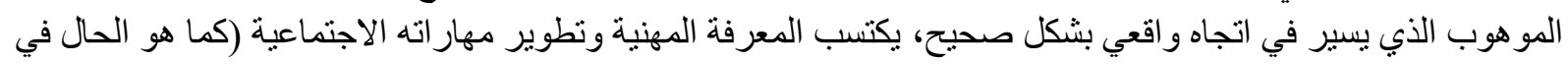

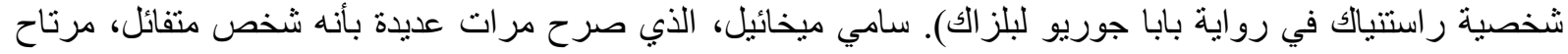

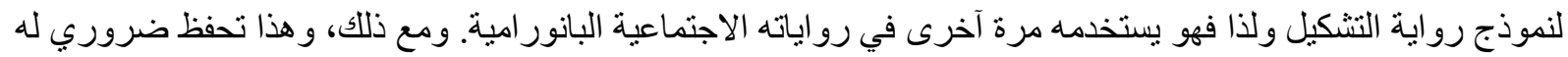

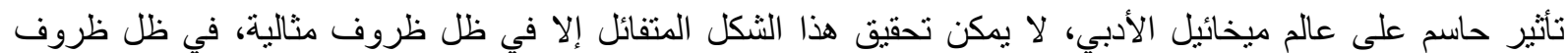
اجتماعية لا توجد إلا في المجتمعات الفاضلة.

كما هو معروف ان ميخائيل هو اديب واقعي مشهور في عالم المثالي، مسار حياة الثخص، ووفقاً لمَّا لمسار حياة

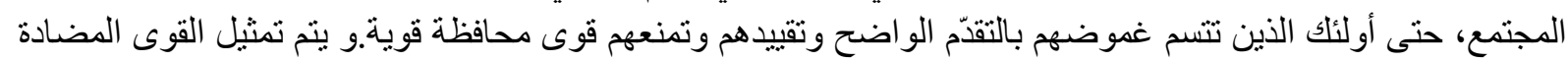

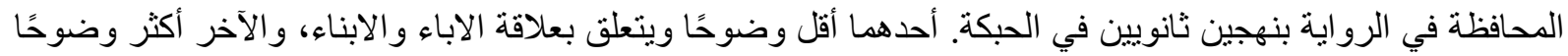

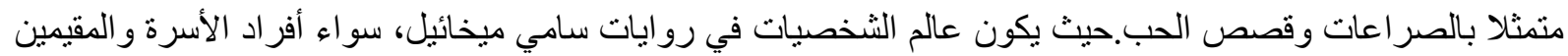

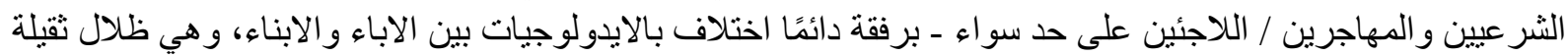

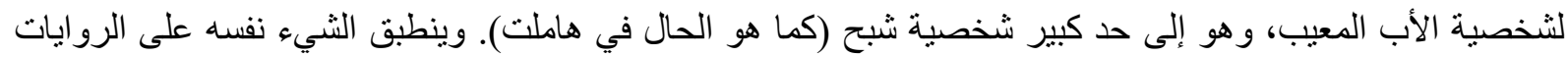

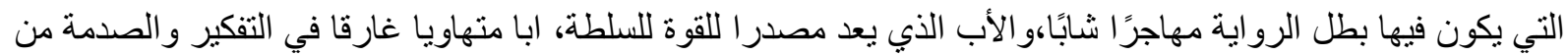

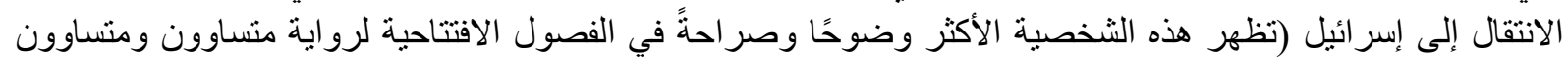

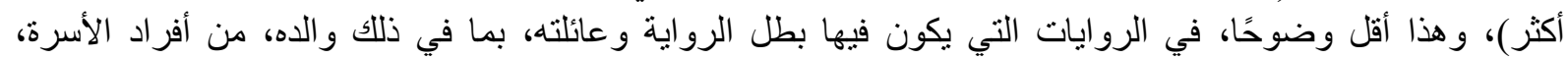

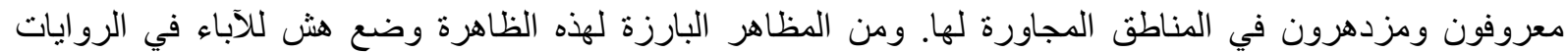

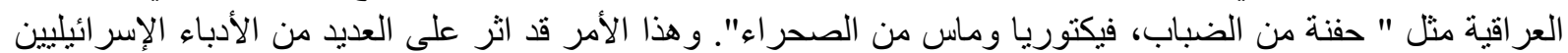

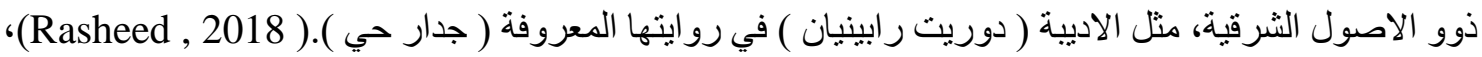

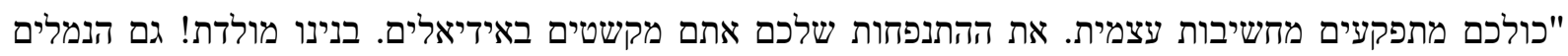

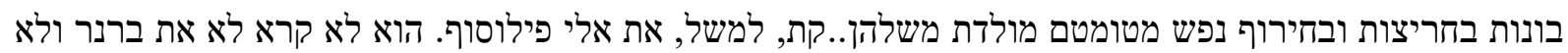

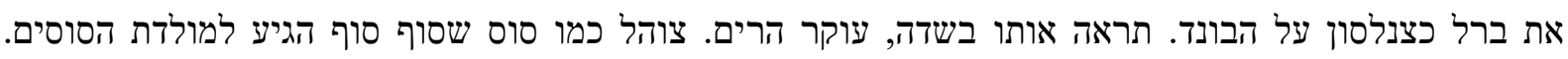

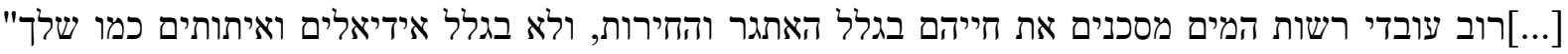

ההרגשה שלי, ב"שוי"( מיכאל , 2001 )

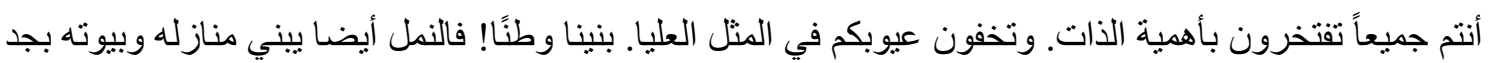

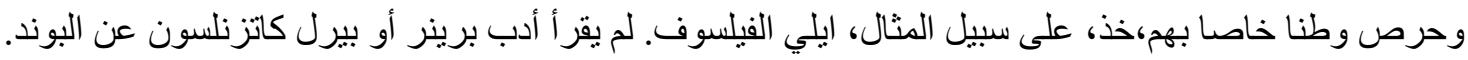
انظر إليه في الحقل، يتسلق الجبال. مندفعا كحصان وصل أخيرًا إلى وطن الخيول. [...] معظم موظفي دائرة المياه

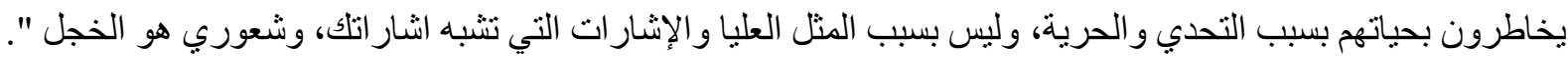


لهذه الظاهرة العديد من الانعكاسات في أدب ميخائيل. ومن بينها اختيار ميخائيل الثاب الانضمام إلى الحركة الإنة

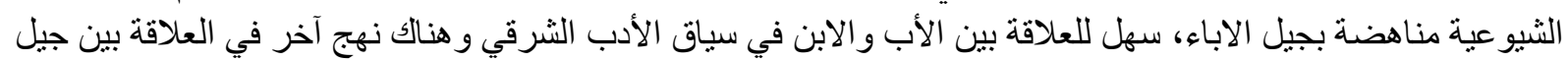

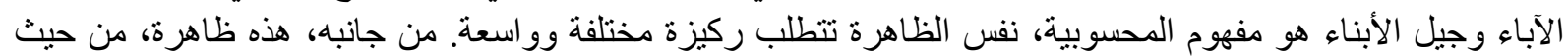

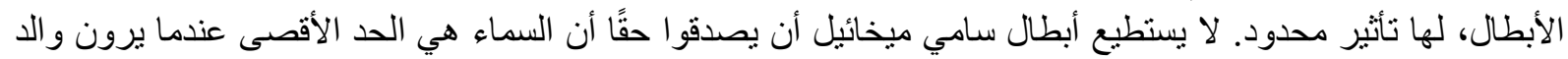

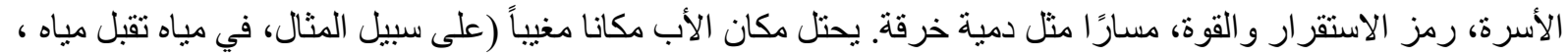

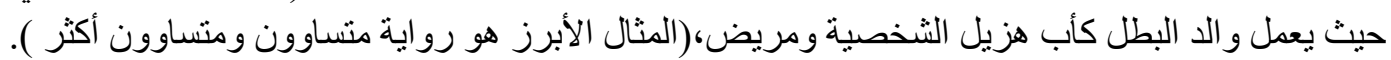

"נאזימה ! שאלתי אם נשאר משהו. משהו לאכול".

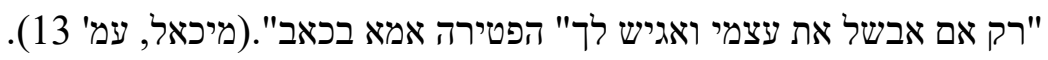

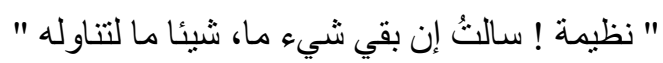

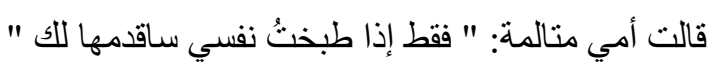

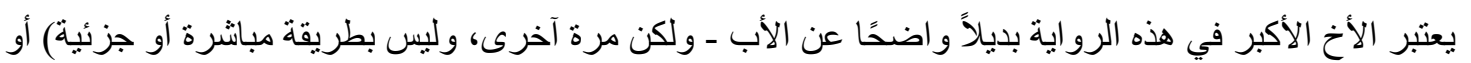

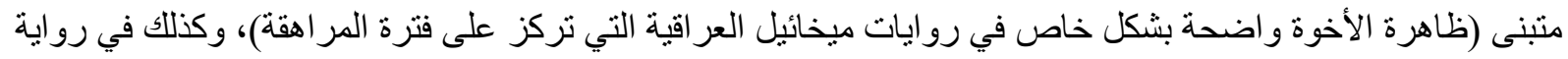

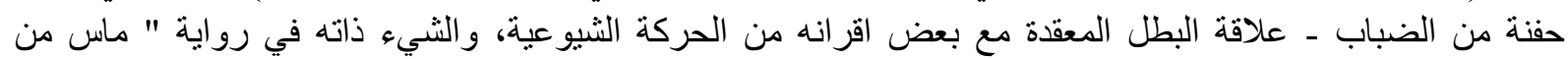

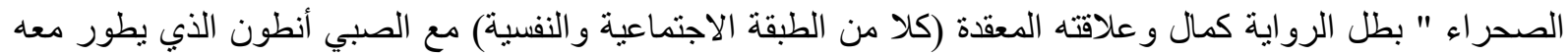

الأبطال علاقة معقدة).

إن محور الحبكة الثانوية الآخرى الذي يحد ويحدد الإمكانات التقدية قصة الحب أكثر وضوحا وأكثر أهمية من

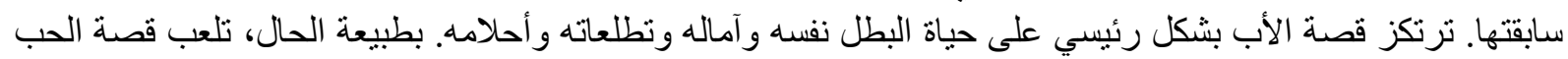

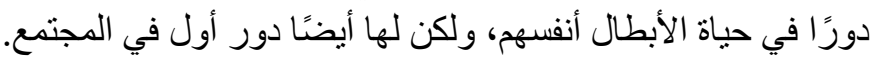

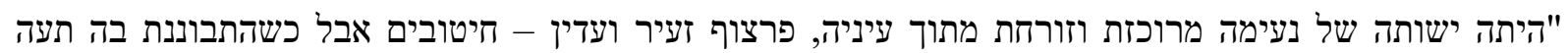

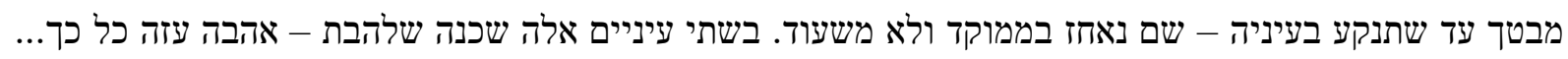
מי הגבר שיוכל לה ? " (מיכאל,עמ' 16 - 17 )

كانت شخصية نعيمة مركزة وبهية من خلال عينيها، وجه صغير وجميل الطلة - بيد انكا إذا امعنت النظر إليها

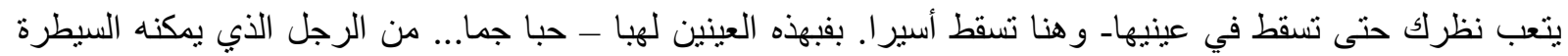

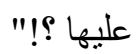

إن المنطق ور اء الاختيار المحدد لأدوار العشاق، ومصبر هذا الاقتران في الحاضر السردي وفي بعض الأحيان

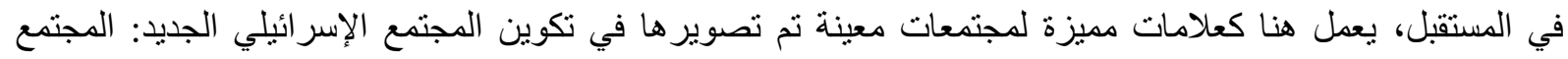

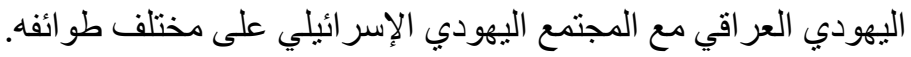

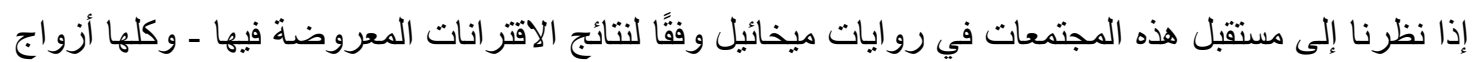

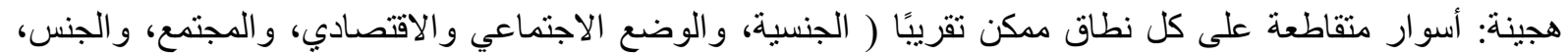

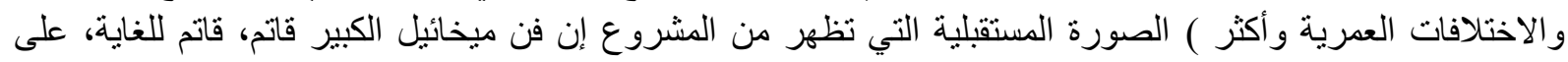

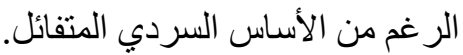

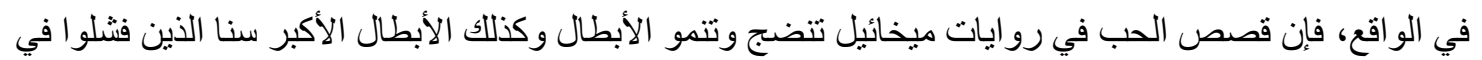

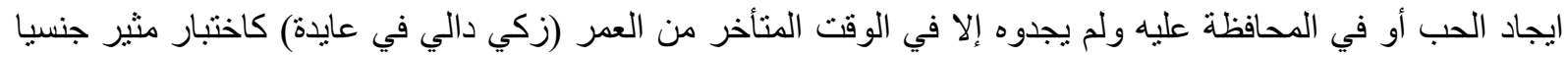

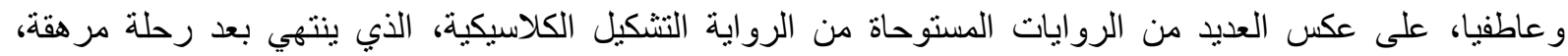

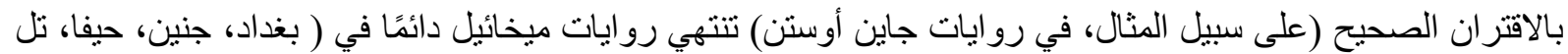
ابيب ) بالكارثنة.

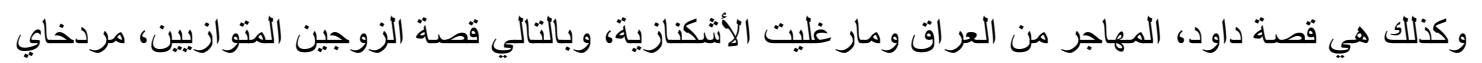

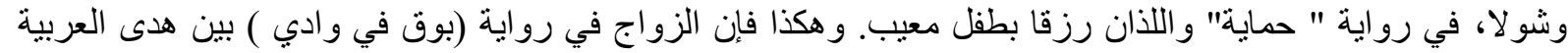

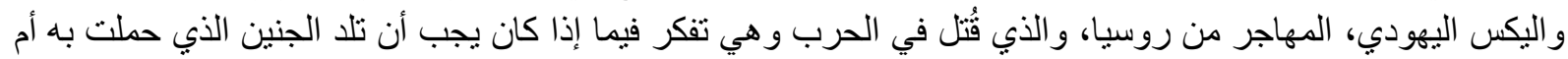




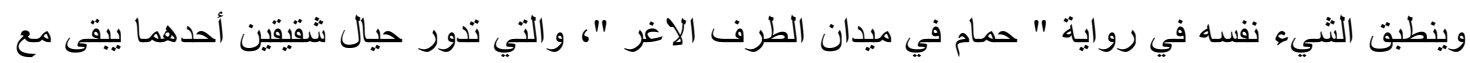

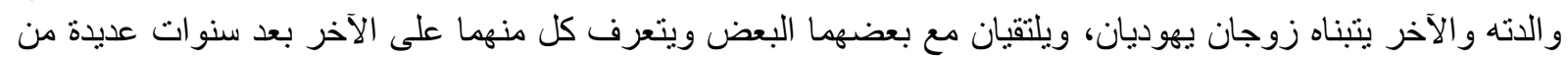

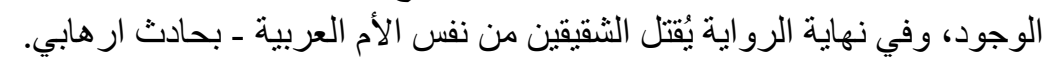

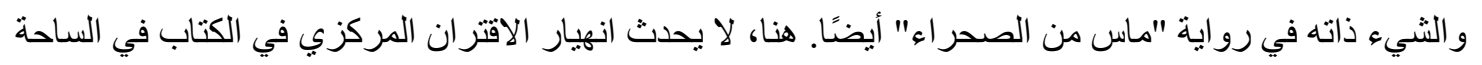

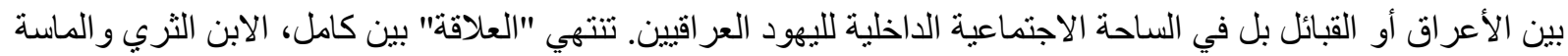

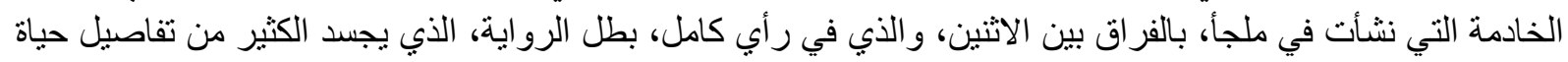

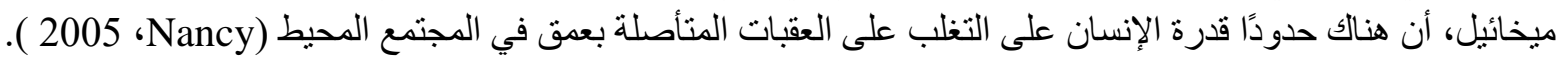

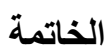

1-الرواية الاجتماعية البانورامية هي نوع فرعي من الرواية الواقعية ظهرت في اوربا في منتصف القرن التاسع عشر نتيجة للتغير ات الاجتماعبة و السياسية آنذاكل

2-إن سامي ميخائيل هو كاتب اجتماعي بانور امي بامتياز لما حفلت نصوصه الروائية من موضواعينه عات وأحداث سياسية

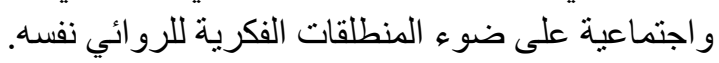

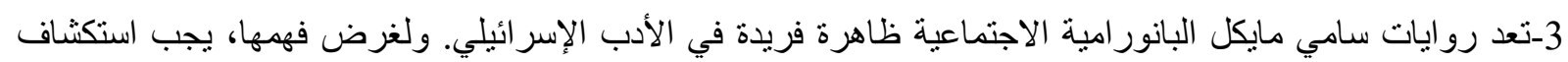

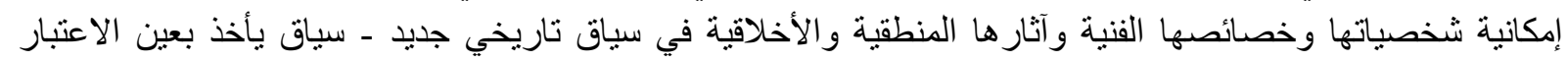

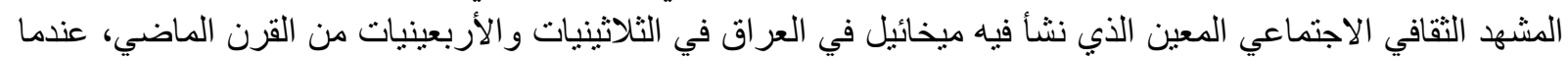

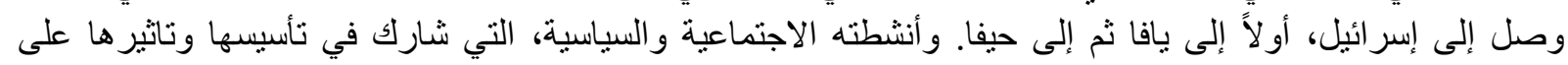

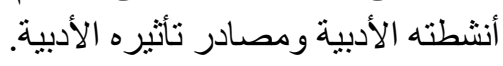

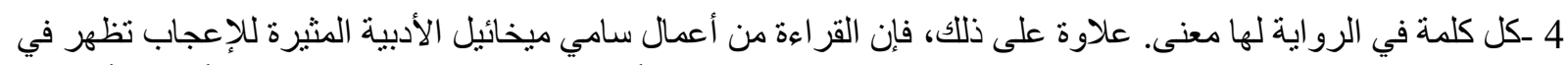

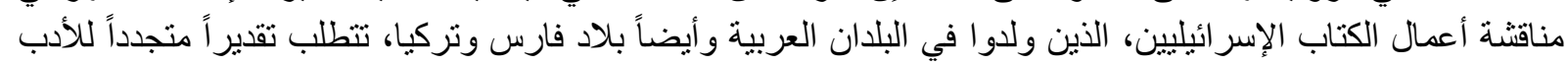

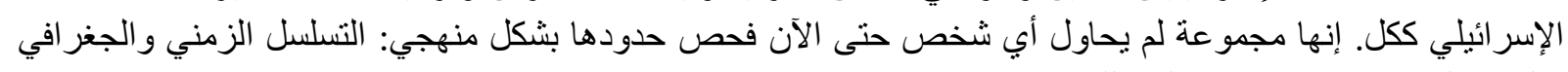
و السرد الوجودي و الإثني وما إلى ذلت مانك.

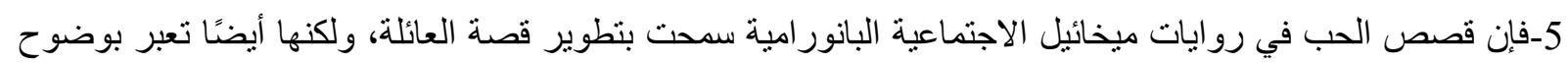

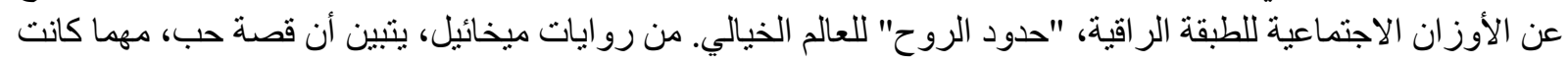

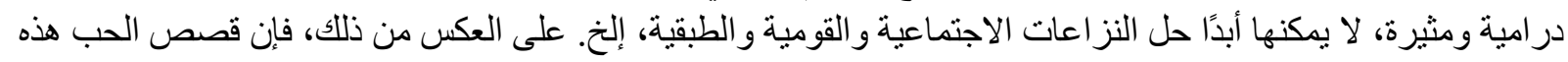

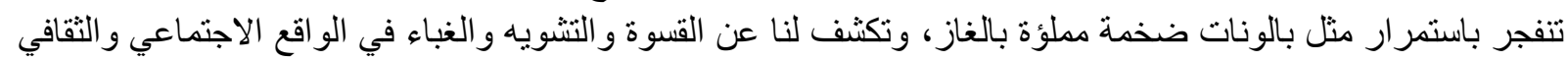
الذي ينخرط فيه الثرق أوسطيون في القومية الحديثة.

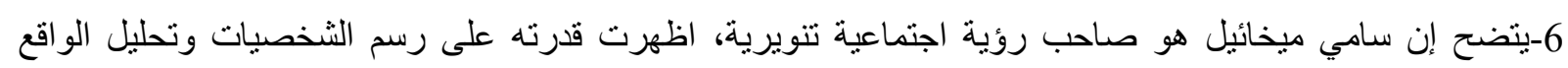

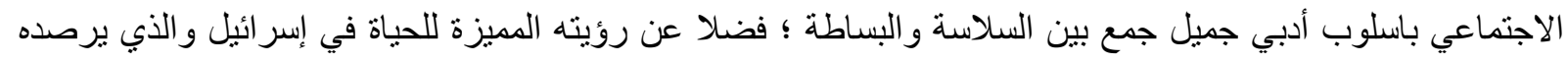




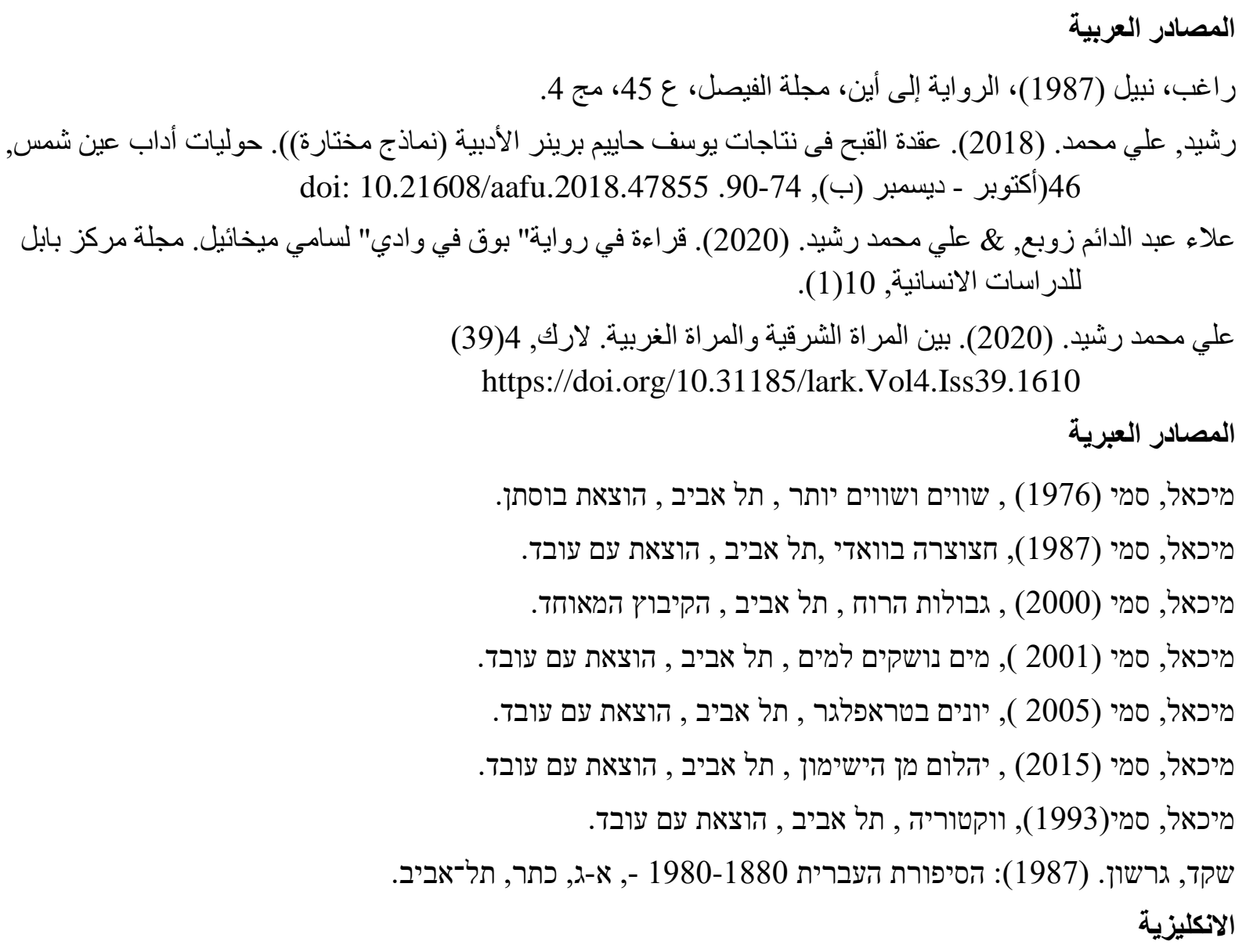

Armstrong, N. (1987). Desire and Domestic Fiction: A Political History of the Novel. New York: Oxford University Press.

Burgess, A. (1967). The Novel Now: A Student's Guide to Contemporary Fiction. London: Faber.

Doody, M. A. (1996). The True Story of the Novel. New Brunswick. NJ: Rutgers University Press.

Hoffman, J. M. (2004). In the Beginning: A Short History of the Hebrew Language. New York: NYU Press.

Kuzar, R. (2001). Hebrew and Zionism: A Discourse Analytic Cultural Study. Berlin \& New York: Mouton de Gruyter.

Laufer, A. (1999). Hebrew Handbook of the International Phonetic Association. england: Cambridge University Press.

McKeon, M. (1987). The Origins of the English Novel, 1600-1740. Baltimore: Johns Hopkins University Press. 